\title{
Demineralization-remineralization dynamics in teeth and bone
}

\author{
This article was published in the following Dove Press journal: \\ International Journal of Nanomedicine \\ 19 September 2016 \\ Number of times this article has been viewed
}

\author{
Ensanya Ali Abou Neel ${ }^{1-3}$ \\ Anas Aljabo ${ }^{3}$ \\ Adam Strange ${ }^{3}$ \\ Salwa Ibrahim ${ }^{3}$ \\ Melanie Coathup ${ }^{4}$ \\ Anne MYoung ${ }^{3}$ \\ Laurent Bozec ${ }^{3}$ \\ Vivek Mudera ${ }^{4}$ \\ 'Division of Biomaterials, Operative \\ Dentistry Department, Faculty of \\ Dentistry, King Abdulaziz University, \\ Jeddah, Saudi Arabia; ${ }^{2}$ Biomaterials \\ Department, Faculty of Dentistry, \\ Tanta University, Tanta, Egypt; \\ ${ }^{3}$ Department of Biomaterials and \\ Tissue Engineering, UCL Eastman \\ Dental Institute, London, UK; ${ }^{4} \mathrm{UCL}$ \\ Institute of Orthopaedics and \\ Musculoskeletal Sciences, Royal \\ National Orthopaedic Hospital, \\ Stanmore, London, UK
}

Correspondence: Ensanya Ali Abou Neel Division of Biomaterials, Operative Dentistry Department, Faculty of Dentistry, King Abdulaziz University, PO Box 80209, Jeddah 21589, Saudi Arabia

Tel +966596820208

Email eabouneel@kau.edu.sa

\begin{abstract}
Biomineralization is a dynamic, complex, lifelong process by which living organisms control precipitations of inorganic nanocrystals within organic matrices to form unique hybrid biological tissues, for example, enamel, dentin, cementum, and bone. Understanding the process of mineral deposition is important for the development of treatments for mineralizationrelated diseases and also for the innovation and development of scaffolds. This review provides a thorough overview of the up-to-date information on the theories describing the possible mechanisms and the factors implicated as agonists and antagonists of mineralization. Then, the role of calcium and phosphate ions in the maintenance of teeth and bone health is described. Throughout the life, teeth and bone are at risk of demineralization, with particular emphasis on teeth, due to their anatomical arrangement and location. Teeth are exposed to food, drink, and the microbiota of the mouth; therefore, they have developed a high resistance to localized demineralization that is unmatched by bone. The mechanisms by which demineralizationremineralization process occurs in both teeth and bone and the new therapies/technologies that reverse demineralization or boost remineralization are also scrupulously discussed. Technologies discussed include composites with nano- and micron-sized inorganic minerals that can mimic mechanical properties of the tooth and bone in addition to promoting more natural repair of surrounding tissues. Turning these new technologies to products and practices would improve health care worldwide.
\end{abstract}

Keywords: demineralization, remineralization, teeth, bone and calcium phosphates

\section{Introduction}

Enamel, dentin, cementum, and bone are natural composites of both organic and inorganic components. Bone, cementum, and dentin are specialized connective tissues, while enamel has an ectodermal origin. For the specialized connective tissues (bone, cementum, and dentin), collagen type I constitutes $\sim 90 \%$ of their organic component; $;, 2$ noncollagenous proteins form the remaining. On the other hand, enamel has little or no collagen, and its organic matrix is made up of noncollagenous protein, which is $90 \%$ amelogenin. ${ }^{3}$ The inorganic component of these hard tissues consists of biological apatite, $\mathrm{Ca}_{10}\left(\mathrm{PO}_{4}\right)_{6}(\mathrm{OH})_{2}$. Enamel has more inorganic content ( $\sim 90 \%$ prismatic crystals) than dentin and bone $(\sim 70 \%)$ and cementum $(45 \%)$. The unit cell of biological apatite is hexagonal in shape; repetitions of the unit cells produce crystals of various sizes. In dentin, the crystals are plate like of $50 \mathrm{~nm}$ length, $20 \mathrm{~nm}$ width, and $2-5 \mathrm{~nm}$ thickness. ${ }^{4}$ In bone, the crystals are known to be $\sim 2-6 \mathrm{~nm}$ thick, 30-50 nm wide, and 60-100 nm long. ${ }^{5}$ However, they are bigger and highly oriented in enamel than in bone and dentin, making it the hardest tissue in the body. Due to the presence of a variety of substitutions and vacancies within the biological apatite, its calcium-phosphate ratio is different from that of stoichiometric hydroxyapatite (HA, 1.67). Enamel apatite, 
resembling the stoichiometric HA, has fewer substitutions than bone and dentin mineral. ${ }^{6}$ Examples of ion substitution that could occur in biological apatite include substitution of calcium ions with magnesium and sodium, substitution of hydroxyl sites with fluoride and chloride, and substitution of both phosphate and hydroxyl sites with carbonate. With ion substitutions, a considerable variation in apatite properties could occur, for example, magnesium substitution inhibits crystal growth, carbonate substitution increases solubility, and fluoride substitution decreases the solubility. ${ }^{3}$ The carbonate content of bone and teeth HA is $4 \%-8 \%$; with age, the carbonate content increases but the hydrogen phosphate decreases. ${ }^{3,4}$ The ratio of inorganic-to-organic contents varies according to the tissue; such variation reflects the properties of each tissue. For example, with high inorganic content, enamel is tougher and more highly resistant to force than any other hard tissues in the body. With high organic content, however, dentin is more resilient than enamel and therefore provides a resilient layer under enamel and cementum.

Furthermore, these hard tissues have different regenerative capacity. Unlike ameloblasts and odontoblasts, which leave no cellular bodies in their secreted products during the later stage of apposition, many cementoblasts and osteoblasts become entrapped by the formed cementum and bone they produce, becoming cementocytes and osteocytes, respectively. Although bone is a highly adaptive tissue (ie, continually undergoing remodeling), cementum has a very slow regenerative capacity ${ }^{7}$ and is not resorbed under normal conditions. Dentin and enamel develop their definitive structure during odontogensis. Dentin has the capacity to regenerate by the formation of secondary and tertiary dentin, but enamel does not have the regenerative capacity. Unlike skeletal bones, facial bones are derived from both neural crest and paraxial mesoderm and they respond differently to growth factors and mechanical stimuli. ${ }^{8}$

\section{Mineralization of teeth and bone}

Mineralization is a lifelong process, in which an inorganic substance precipitates onto an organic matrix. Normal biological processes include the formation of hard connective tissues, such as bone, dentin, and cementum, in which collagen fibrils form a scaffold for a highly organized arrangement of uniaxially organized calcium phosphate crystals. ${ }^{9}$ Pathological processes of mineralization result in calcification within blood vessels or in, for example, the kidney or formation of gallstones. ${ }^{10}$ Understanding the process of mineral deposition is important for the development of treatments for mineralization-related diseases and also for the innovation and development of scaffolds. However, there are still critical gaps in understanding the process. While the structure of mineralized collagen is now well understood, how mineral precipitates with the spatial and hierarchical order found in tissues is still largely unknown. Cells control the mineralization process of crystal morphology, growth, composition, and location. The molecules of the extracellular matrix (ECM) and a series of enzymes, however, direct the entry and fixation of mineral salts (calcium and phosphate ions) in bone, dentin, and enamel.

\section{Teeth}

Teeth are composed of enamel, pulp-dentine complex, and cementum. Dentine forms the largest portion of a tooth. It is $70 \%$ mineralized by weight, with the organic content accounting for $20 \%$ of the matrix, and the remaining $10 \%$ being water. Type I collagen is the primary component of the organic portion of dentine, accounting for $>85 \%$, with the remaining amounts being collagen types III and V. The noncollagenous part of the organic matrix is composed mainly of dentine phosphoprotein, accounting for $\sim 50 \%$ of the noncollagenous part. The remaining inorganic matrix is composed primarily of HA. ${ }^{11}$ Several studies have suggested that collagen in enamel matrix is completely removed with all other organic components during the course of its mineralization and maturation. ${ }^{12-14}$ These studies refuted the earlier theories that proposed that a small percentage of collagen is retained after enamel maturation. ${ }^{15,16}$ A more recent study concluded that there is minimal collagen content, mostly types I and V, found in mineralized and mature enamel in comparison with dentine. ${ }^{17,18}$ It is commonly believed that HAs are generally encompassed within and coated by the organic material present in the tooth structure. While the physical properties of teeth are largely attributed to the presence of enamel, it is also hypothesized that collagen acts as an active protective protein sheath of the underlying HA crystallite lattice.

Type I collagen, a heterotrimer of two $\alpha 1$ (I) chains and one $\alpha 2(\mathrm{I})$ chain folded in a triple helix structure, has a rod-like structure of $1.5 \mathrm{~nm}$ diameter and $>300 \mathrm{~nm}$ long. The triple helix domain is flanked by nonhelical $\mathrm{N}$ - and C-propetides. This form of collagen, known as procollagen, is secreted from cells, for example, fibroblasts, odontoblasts, and osteoblasts into the extracellular spaces where it is converted into tropocollagen by the removal of N- and C-propeptides. Tropocollagen can then spontaneously self-assemble into fibrils (ie, the fibril is built from the staggered packing of the individual collagen molecules such that there are periodic gaps along the fibril surface and 
channels extending through the fibril ${ }^{19}$ ). Each collagen unit is $\sim 300 \mathrm{~nm}$ long and overlaps neighboring units by $\sim 67 \mathrm{~nm} .{ }^{19}$ Fibrils contain gap regions of $40 \mathrm{~nm}$ between end-to-end collagen units. Packing of collagen is stabilized by weak dispersive and hydrogen interactions as well as by strong intermolecular cross-links. This stabilization is essential for the structural stability and insolubility of collagen in water. ${ }^{20}$ End-to-end elongation and lateral aggregation of collagen fibrils are responsible for increasing its diameter and migration ${ }^{21}$ toward the place where they undergo mineralization, for example, movement of collagen fibrils from the proximal to the distal predentin where the mineralization occurs. ${ }^{3}$ In dentin, collagen type I accommodates $\sim 56 \%$ of mineral in its holes and pores of fibrils. The noncollagenous proteins act as inhibitors, promotors, and/or stabilizers of mineral deposition. For example, glycoproteins prevent premature mineralization until the collagen fibrils become mature and attain their correct dimensions. Dentin matrix protein-1, an acidic phosphoprotein, plays an important role in initiation of nucleation and modulation of the morphology of mineral phase. ${ }^{22}$ During dentinogensis, three types of mineralization usually occur; they include matrix vesicle-derived mineralization (in mantle dentin), ECM molecule-derived mineralization (in majority of dentin), and blood-serum-derived mineralization (in peritubular dentin) ${ }^{23}$ Odontoblasts secrete an acid mucopolysaccharide, for example, chondroitin sulfate, which is a prerequisite for start of mineralization. This mucopolysaccharide is transported to the site of mineralization in dentin matrix; it attracts calcium and serves to transport minerals from cells to the ECM. ${ }^{24}$

In enamel, immediately after initial dentin mineralization at the dentinoenamel junction, ameloblast cells secrete enamel matrix proteins (eg, amelogenin, ameloblastin, and enamelin) and proteinases (matrix metalloproteinase- 20 and kallikrein-related peptidase-4) at the dentin surface. These proteins and proteinases are responsible for immediate mineralization of $\sim 30 \%$ of enamel. The first formed enamel crystals (ribbons) grow between the existing dentin crystals by mineralizing around dentin proteins. These crystal ribbons then elongate at the mineralization front where enamel proteins are secreted. While they are moving away from the dentin surface, the ameloblast start secreting large amounts of enamel matrix proteins. When the entire thickness of enamel is formed, the ameloblasts become protein-resorbing cells (ie, remove enamel matrix proteins); and therefore, additional mineral is required to coincide with the bulk removal of enamel proteins and water to produce enamel with $>95 \%$ mineral content. The formed crystals are long, thin, and parallel ribbons of $26 \times 368 \mathrm{~nm}^{2} ; \sim 10,000-40,000$ ribbons at packing density of 550 crystallites $/ \mu \mathrm{m}^{22}$ form a rod (prism) with $\sim 5 \mu \mathrm{m}$ diameter. ${ }^{26}$ Each ameloblast produces one rod; all rods are organized in a three-dimensional structure. The mineral crystals formed within the enamel rods grow in $c$-axis length parallel to each other all the way from dentinoenamel junction to the tooth surface, while those developed between the rods (ie, interred) have limited lengths and always ordered at angles relative to the rod crystals. Since this process of enamel formation and maturation is a cell-mediated process, completion of mineralization is associated with several morphological changes in ameloblasts; hence, the matrix removal and crystal growth occur efficiently. For calcification, the influx of calcium from the blood to the enamel matrix involves intercellular and transcellular routes. Unlike collagen-based mineralized tissues, no matrix vesicles are associated with mineralization of enamel. The mineral content is reduced from the enamel surface toward the dentinoenamel junction. The position of HA is located between the nanospheres of amelogenin., ${ }^{3,27}$ Therefore, ameloblasts are not only responsible for secreting the enamel matrix proteins and proteinases but also induce mineral formation and finally organize these minerals into rod and interred patterns.

\section{Bone}

During the formation of mineralized bone matrix, osteoblasts first deposit unmineralized osteoid and release mineralnucleating proteins that catalyze the process where osteoid starts to calcify. Mineralization occurs after $\sim 15$ days. The primary phase of mineralization to $\sim 70 \%$ of full mineralization is a rapid process, whereas the secondary phase to full mineralization is slower and can last for several months to years. This process of mineral accumulation within each site of newly formed bone together with the activation frequency of remodeling sites causes a specific mineralization pattern in the bone material. As mentioned above, type I collagen is known to be the predominant component of the ECM of bone, calcifying tendon, dentin, and cementum. Crystals may be formed within the individual type I collagen fibrils, with the same periodicity displayed by the collagen, and along the fibril surfaces in the extrafibrillar spaces between packed collagen fibrils of the bone and dentin fibers. ${ }^{28}$ In 1952, Robinson and Watson ${ }^{29}$ showed that carbonated HA crystals exist within collagen (intrafibrillar deposition) with their $c$-axis nearly parallel with the long axis of the collagen fibril. The crystals are known to be $\sim 2-6 \mathrm{~nm}$ thick, $30-50 \mathrm{~nm}$ wide, and 60-100 nm 
long. ${ }^{5}$ Several studies have shown that the matrix nucleates preferentially form within the gap regions of collagen fibrils, where most crystals are well organized into parallel arrays, in almost continuous dark bands. ${ }^{5,19}$ While the mineral precipitates preferentially in the gaps between the collagen fibrils, the crystals have been shown to grow and eventually exceed the size of the gap. ${ }^{19}$ Furthermore, mineral exists both within and external to the collagen fibrils (interfibrillar deposition); however, it is generally accepted that the majority of the mineral exists within the fibrils. ${ }^{30}$ Interfibrillar mineralization of collagen is directed by the collagen matrix, ${ }^{31}$ which leads to nanostructured architecture consisting of uniaxially orientated nanocrystals of HA embedded within and roughly aligned parallel to the long collagen fibril axis. Previous studies have suggested that type I collagen polypeptide stereochemistry and other factors are fundamental in the initial events of mineral deposition with the intrafibrillar spaces of the molecule. ${ }^{32,33}$ The side chains of polypeptide-charged amino acids are thought to contribute binding sites for calcium and phosphate ions found in the circulating supersaturated fluid of the tissues. ${ }^{32}$ The configurations would conceptually bring these ions into close association and lead to their nucleation. Apatite growth and development would follow initial nucleation events to result in platelet-shaped crystals growing preferentially along collagen assemblies. ${ }^{32,34}$ It is clear that not all collagenous tissues mineralize and investigating the process in vivo is difficult. Therefore, many of the studies that have investigated the possible physicochemical mechanisms of mineralization used in vitro models.

The control of bone biomineralization is dynamic and complex with many theories, describing the responsible mechanisms, and many factors have been implicated as agonists and antagonists of mineralization; the deregulation of which can lead to pathological extraskeletal mineralization. The crystallization process can be considered from several different perspectives: 1) the development of crystallinity in a mineral phase developed directly from a supersaturated solution of the mineral ions, 2) the presence of polymeric (protein) polyions in the mineralizing system and how they might interact in vitro with the free ions or with nanoclusters of $\mathrm{Ca}$ and $\mathrm{PO}_{4}$ ions to modulate the mineralization process, 3) small integrin-binding ligand, N-linked glycoproteins (SIBLINGs) and how they might be delivered in vivo to regulate mineralization at specific sites, including the processes of nucleation, crystal growth, crystal morphology, and size regulation, and 4) the delivery of sequestered, vesicular nanoclusters of $\mathrm{Ca}$ and $\mathrm{P}$ directly from the cell or the mitochondria to the mineralization front. ${ }^{35}$ Veis and Dorvee ${ }^{35}$ speculated that it is likely that some common mechanisms may be applicable in all cases.

Mineralization was initially viewed as a classical precipitation and growth of apatite crystals directly from interstitial fluid supersaturated with calcium and phosphate phases. Studies have shown that serum is a metastable solution from which calcium phosphate precipitates in the presence of calcifiable templates such as collagen, elastin, and cell debris. ${ }^{36,37}$ Recently, it was demonstrated that apatite formation in bone and teeth does not occur directly by the association of ions from solution but is preceded by an amorphous calcium phosphate (ACP) precursor phase that may later transform into octacalcium phosphate before becoming HA, ${ }^{38}$ although the mechanism of this pathway is under debate. ${ }^{39,40}$ It has been suggested that calcium phosphate precipitation in vitro is kinetically driven, meaning that the mineral does not crystallize directly into the most thermodynamically stable product but instead precipitates first into the kinetically most accessible form, ACP, which is subsequently transformed into the most thermodynamically stable phase. ACP formation is thought to proceed through subnanometer-sized prenucleation clusters with a chemical composition $\mathrm{Ca}_{9}\left(\mathrm{PO}_{4}\right)_{6}$, which are stable clusters present in solution before nucleation as was recently demonstrated for $\mathrm{CaCO}_{3} \cdot{ }^{41}$ However, the role of these nanometer-sized clusters as building blocks for ACP formation has been debated for many years. ${ }^{40}$ The origin of the mineral and how it infiltrates the collagen fibrils are still unknown.

ECM noncollagenous proteins (NCPs, now known as SIBLING) are believed to control several aspects of the mineralization process, specifically through the mechanisms of inhibition and promotion by phosphoproteins, glycoproteins, Gla-containing proteins, and proteoglycans. ${ }^{31}$ It has been shown that protein concentration and whether the protein is free or immobilized can profoundly affect function in precipitation models. Presently, there is no clear role of these SIBLINGs, although it has been suggested that SIBLINGs regulate solution crystal growth by an epitaxial relationship between specific crystallographic faces and specific protein conformers. ${ }^{31}$ Osteocalcin and osteopontin are two of the most abundant noncollagenous proteins, and both have been shown to influence the deposition of mineral within the collagen fibril-rich bone ECM. In vitro studies have shown osteocalcin and osteopontin control HA nucleation, size, shape, and orientation. ${ }^{42,43}$

Regulation of the mineralization process is also known to rely largely on inorganic pyrophosphate (PPi), a potent inhibitor of mineralization. Osteoblast and osteocyte-derived 
matrix vesicles control extracellular PPi levels with a host of factors, at least three other molecules: nucleotide pyrophosphatase phosphodiesterase 1, ankylosis protein (ANK), and tissue-nonspecific alkaline phosphatase (TNAP). TNAP is an enzyme that hydrolyses and inactivates PPi and is normally expressed at sites of mineralization during development. Loss of TNAP function results in hypomineralized bone. ${ }^{44-46}$ Conversely, ANK is expressed in nonmineralizing tissues, where it transports PPi to the extracellular space to antagonize mineralization. Loss of functional mutations in ANK causes hypermineralization and the formation of bone spurs or bone-like hardening of tendons and ligaments of the spine. ${ }^{47}$ Much of the in vivo evidence regarding the role of specific proteins comes from their distribution and genetic knockout studies. However, proteins such as osteopontin have multiple roles, complicating interpretation. Tissue localization can give clues to a role but does not provide any functional information. ${ }^{30}$

How $\mathrm{Ca}$ and $\mathrm{PO}_{4}$ ions are delivered to the mineralization front is still a matter of debate. Pioneering studies have suggested the role of mitochondria in taking in large amounts of $\mathrm{Ca}$ and $\mathrm{PO}_{4}$ ions, accumulating them, and delivering calcium phosphate in membrane bound vesicles to the extracellular spaces of mineralizing cartilage and bone. ${ }^{35,48,49}$ Matrix vesicles are extracellular, membrane-invested vesicles $50-200 \mathrm{~nm}$ in diameter and are formed by polarized budding from the surface membrane of chondrocytes, osteoblasts, and odontoblasts. The signals that release matrix vesicles are not well understood, although the concentrations of intracellular calcium and extracellular phosphate may be important..$^{50}$ Mineralization begins with the formation of HA crystals within matrix vesicles, followed by propagation of HA through the membrane into the ECM. The origin of calcium and phosphate within the vesicles has not been elucidated. When the accumulation of calcium and phosphate exceed the solubility point for calcium phosphate, deposition of HA occurs within the matrix vesicles. ${ }^{50}$ In the second step, HA crystals penetrate the matrix vesicle membrane and are elongated into the extracellular space. The ratio of phosphate ions to PPi is crucial in the second step of mineralization. $\mathrm{PPi}$, which inhibits the formation of $\mathrm{HA},{ }^{51}$ is formed by nucleotide pyrophosphatase phosphodiesterase 1. Alkaline phosphatase hydrolyses PPi to generate phosphate ions. The mechanisms by which vesicles may be broken open and their mineral contents transferred and localized to the collagen are still a subject of current study and debate. ${ }^{35}$ There is abundant evidence that the mineral-containing intracellular vesicles do exist, and their contents in different situations contain ACP or apatite needle-like crystals. Mahamid et $\mathrm{al}^{52}$ showed that mineral is released in globules (presumably ACP) from cells at the growth zone. Further questions that remain unsolved are those surrounding the mechanisms by which the mineral is transformed from the mitochondria to the mineralizing matrix, then reordered, in essence dissolved, and recrystallized on the collagen fibril matrix on the fibril surfaces, or within the fibrils themselves. ${ }^{35}$

\section{Role of calcium and phosphate ions in teeth and bone}

Calcium phosphate is fundamental for the formation of bone and teeth and is essential for achieving optimal peak bone mass in the first 2-3 decades of life and for the maintenance of bone in later life. ${ }^{53}$ Mineral concentration is a major determinant of the elastic modulus of the bone matrix. As the mineral fraction of the bone ECM increases, hence does the elastic modulus. ${ }^{54}$ Therefore, different tissues in the body can provide either rigidity (high mineral content) or flexibility (low mineral content).

The HA in teeth varies from empirically derived HA, and HA found in bones, as the dental version, is often calcium deficient due to fluorine substitutions - Equations 1 and 2 that shows the stoichiometric formula of HA (Equation 1). The formula of HA shows the sites for atomic substitution (Equation 2). This HA is calcium deficient and carbonated. $\mathrm{X}$, calcium substitution with metal cation; Y, phosphate substitution with carbonate; and $Z$, hydroxide substitution with fluoride. ${ }^{55-57}$

$$
\begin{aligned}
& \mathrm{Ca}_{5}\left(\mathrm{PO}_{4}\right)_{3}(\mathrm{OH}) \\
& \mathrm{Ca}_{10-\mathrm{X}} \mathrm{Na}_{\mathrm{X}}\left(\mathrm{PO}_{4}\right)_{6-\mathrm{Y}}\left(\mathrm{CO}_{3}\right)(\mathrm{OH})_{2-\mathrm{Z}} \mathrm{F}_{\mathrm{Z}}
\end{aligned}
$$

Calcium-deficient carbonated HA comprises the major substitution activity that takes place. Other much smaller number of substitutions occur where calcium ions, $\sim 1 \%$, is replaced by other metal ions, including potassium, sodium, and magnesium. ${ }^{58}$ The presence of carbonates and other ionic substitutions significantly disrupts the crystal lattice in HA. This weakens the HA, increasing its susceptibility to acid attack and solubility. ${ }^{59}$ The carbonate content of dentine is $5 \%-6 \%$, while in enamel it is $3 \%$, and the HA crystal size in dentine is much smaller than those in enamel, thus making dentinal matrix much more vulnerable to acidic attack. ${ }^{60}$

With age, the crystallinity of dental HA decreased but the carbonate content increased. The $\alpha$-lattice constant, 
associated with the carbonate content, decreased while the c-lattice, associated with hydroxyl sites, does not change significantly with age. Increased crystal structure disorder and reduction in crystallinity are expected with higher number of planar carbonate ions substituting for tetrahedral phosphate ions in the apatite structure. ${ }^{61}$ Both A- and B-type of carbonate substitutions are present but the B-type (carbonate for phosphate) is greater than the A-type (carbonate for hydroxyl). ${ }^{61}$ Since c-lattice parameter is nearly age independent; this indicates that the phosphate tetrahedron represents the main site of carbonate substitution in the apatite lattice. ${ }^{61}$ A decrease in crystallinity and increase in carbonate content favor the dissolution of dental apatite. This is a change in material phase and the composition of dental mineral, while also reducing crystal size. ${ }^{61}$ The carbonate content has a significant effect on the reactivity and solubility of physiological HA.

Calcium, phosphate, and fluoride ions play an important role in the battle between demineralization and remineralization processes and accordingly modify the susceptibility of tooth to caries progression. ${ }^{62}$ During demineralization, calcium release precedes phosphate release from enamel, dentin, and cementum. Therefore, using calcium rather than phosphate to suppress the demineralization process would be effective. ${ }^{63}$

\section{Demineralization-remineralization dynamics in teeth}

Demineralization is the process of removing minerals ions from HA crystals of hard tissues, for example, enamel, dentin, cementum, and bone. Restoring these mineral ions again to the HA crystals is called remineralization. Both processes occur on the tooth surface, and a substantial number of mineral ions can be lost from HA without destroying its integrity but high sensitivity to hot, cold, pressure, and pain would be expected. Lacking of the integrity of HA latticework, however, produces cavities. Demineralization is a reversible process; hence, the partially demineralized HA crystals in teeth can grow to their original size if they are exposed to oral environments that favor remineralization. ${ }^{64}$

\section{Demineralization}

Similar to bone, teeth are composites comprised of the phosphate-based mineral HA in the enamel, collagen in the dentine, and living tissues. ${ }^{65-67}$ However, it is the anatomical arrangement and location of teeth that sets them apart from bones. ${ }^{68}$ Exposed to food, drink, and the microbiota of the mouth, teeth have developed a high resistance to localized demineralization unmatched by other mineralized tissues. ${ }^{59,69}$ This resistance is chiefly due to the enamel layer that covers the crown of the teeth. ${ }^{70,71}$

Chemical demineralization of teeth is caused by acidic attack through two primary means: dietary acid consumed through food or drink and microbial attack from bacteria present in the mouth. ${ }^{69,72,73}$ Published literature in this area seeks to apply chemical theory to the erosion of dental hard tissues, chiefly enamel. ${ }^{59,74,75}$

During an acidic attack, or a typical demineralization regime, chemical dissolution of both the organic and inorganic matrix components takes place. This is brought about by the water content of enamel and dentine, which facilitate acid diffusion in and mineral content out of tooth. ${ }^{60}$

\section{Etiology and risk factors: a multifactorial process}

Demineralization and the subsequent erosion and/or loss of tooth surface versus remineralization are dynamic processes that are dependent on several modifying factors, as shown in Table 1. These factors are split into two main groups, extrinsic and intrinsic, which can be altered by the last group, the modifying factors. Extrinsic factors include diet and medication. Intrinsic factors are mostly diseases that can sometimes be treated with medications that are themselves extrinsic factors of erosion. Modifying factors can be variations in the biochemical characteristics of an intrinsic or extrinsic factor, behavioral patterns such as regular tooth brushing, some of which can also be classed as socioeconomic factors.

Erosion and carious lesions are the two main consequences of demineralization. Public awareness of dental erosion is still not widespread, and its differential diagnosis among dental professionals has proven to be a challenge. ${ }^{76}$ The dietary consumption of soft or fruit-based drinks in the developed world is thought to be over half of all of the liquids consumed. ${ }^{77}$ The spread of the commercialization of the soft drinks market has increased by $56 \%$ over the past 10 years and is growing by a rate of $2 \%-3 \%$ yearly. ${ }^{78}$ In 2002, the consumption of these high acid drinks was

Table I Interaction of different factors in relation to tooth surface loss

\begin{tabular}{|c|c|c|c|}
\hline Biological & Chemical & $\begin{array}{l}\text { Health and } \\
\text { education }\end{array}$ & Behavioral \\
\hline Saliva flow & $\mathrm{pH}$ type & Current health & Eating habits \\
\hline $\begin{array}{l}\text { Soft tissue } \\
\text { anatomy }\end{array}$ & Acid type & $\begin{array}{l}\text { Socioeconomic } \\
\text { status }\end{array}$ & $\begin{array}{l}\text { Drinking } \\
\text { habits }\end{array}$ \\
\hline $\begin{array}{l}\text { Tooth } \\
\text { anatomy }\end{array}$ & $\begin{array}{l}\text { Chelation } \\
\text { potential }\end{array}$ & $\begin{array}{l}\text { Medication and } \\
\text { drugs }\end{array}$ & $\begin{array}{l}\text { Brushing } \\
\text { frequency }\end{array}$ \\
\hline
\end{tabular}


predicted to show an increase in dental issues over the following 5 years. ${ }^{74,79}$ This has been shown to be the case, as repeated studies have shown erosion throughout different demographic groups..$^{55,77,78,80,81}$

Erosion and its extrinsic causative factors have been included in the UK Children's Health Survey since 1993, and a trend toward higher prevalence of erosion in those who often consumed carbonated drinks was shown. ${ }^{82}$ In the UK in $2003,>50 \%$ of 5-6 years old had exhibited significant enamel erosion, linked to the consumption of acidic drinks. Furthermore, $25 \%$ of 11 - to 14-year olds had significant erosion, rising to $77 \%$ in 20 - to 25 -year olds. ${ }^{83,84}$ A recent study in 2015 showed an increase in pediatric dental hospital admissions, with cases strongly linked to sugar erosion. ${ }^{85}$ There is a widespread misunderstanding by patients that the extraction of primary teeth is not a matter of concern, since these will be replaced by permanent teeth. This has been repeatedly shown to be false, and the damage done by the primary teeth issues may be affecting the future health of the permanent teeth. ${ }^{66,80,86,87}$ Previous in vitro models were made on the belief that the tooth-acid interactions last for several minutes. However, more recent in vivo studies suggest that the in vitro tooth-acid models should focus on the acid interaction for 30 seconds. This would better represent in vivo conditions. ${ }^{78,86,88}$

The most recent study in the US has shown that $79 \%$ of adults have at least moderate evidence of tooth decay; regardless of demographic, the key feature was the excessive daily consumption of fruit juices and soft drinks. ${ }^{89}$ The most recent study in the Peoples' Republic of China showed 89\% tooth wear among 15 years old, with $7 \%$ showing dentine exposure; a mark of the severity of the erosion. ${ }^{90}$ Other studies from Japan and India also showed comparable data for early-stage tooth erosion..$^{91,92}$ Modifying behavioral factors that affect dietary consumption include types of drinks consumed, method by which a drink is consumed, and frequency of drinking. For example, an increase in agitation when a drink is swished around the mouth will enhance the dissolution process. ${ }^{93}$ Moreover, several medication and asthmatic inhalers were shown to induce xerostomia by reducing salivary flow, in addition to decreasing its $\mathrm{pH}$; thus, weakening its overall buffering effect against intrinsic and extrinsic acids. ${ }^{94,95}$ Saliva is considered one of the most important biological factors in dictating the intraoral neutralizing effects of acid exposure. Pathogenesis of dental erosion is directly related to the buffering capacity and rate of secretion of saliva. ${ }^{96}$

The mineralization percentage of permanent teeth is higher than that of primary teeth; ${ }^{68}$ nevertheless, adults frequently experience the effects of acid damage on teeth. Mechanically, the teeth are softer and weakened, although there is no change in the brittleness. Intrinsic factors that may lead to erosion include gastroesophageal reflux, often seen in diabetic and obese individuals, bulimia nervosa, and dental rumination. Diseases such as bulimia nervosa have the symptom of selfinduced vomiting, which can be a leading cause in dental erosion if occurring often enough. For gastroesophageal reflux, it is defined as a normal physiologic retrograde flow of gastric contents and acid regurgitation into the esophagus and sometimes mouth, which occurs mostly postprandial, after meals, for $\sim 1$ hour. ${ }^{97}$ Irrespective of the cause, excessive stomach acid has a deleterious effect on dental health. Endogenous acids has a $\mathrm{pH}$ of 1.2, that is well below the critical $\mathrm{pH}$ for fluoroapatite (FAP) and HA dissolution, ${ }^{66,98,99}$ thus leading to rapid demineralization of tooth surfaces. Regardless of the type of causative factors, teeth eroded by acid are more likely to crack or chip if damaged and are harder to repair. ${ }^{100,101}$ The areas of structural weakness that have been demineralized are also targets for caries formation. ${ }^{74,102,103}$ Bacteria can easily colonize the demineralized areas of the tooth and, with a combination of their own acid formation, are able to penetrate into the dentine..$^{81,104}$ The dentinal contribution of the demineralization-assisted caries is higher than when acid drinks are not involved and is a marker of the severity of the caries.

\section{Bacteria}

Dental caries is the most common childhood chronic infectious disease. It is caused by the interaction of bacteria, mostly Streptococcus mutans, and sugar on tooth enamel surface. Bacteria breakdown fermentable carbohydrate such as glucose, sucrose, and fructose and cause an acidic environment that leads to demineralization and resultant carious lesions. ${ }^{98,99}$ There are several theories proposed as to how oral bacteria are actually acquired. At birth, the oral cavity is known to be effectively sterile; however, acquisition is achieved via transmission from food/milk/water, from parents, or from oral mucosa shedding surface during eruption of primary dentition. The most widely accepted hypothesis with regard to the role of bacteria in acid production and caries formation is the "ecological hypothesis", where dental plaque is defined as a dynamic microbial ecosystem in which nonmutans bacteria are key players for maintaining dynamic stability. ${ }^{93}$ S. mutans, Streptococcus sobrinus, and lactobacilli are the main oral cariogenic pathogens due to their ability to produce high levels of lactic acid following sugar fermentation and their resistance to the adverse effects of low 
pH. ${ }^{105,106}$ In some studies, S. mutans were seen to be $>30 \%$ of oral microflora in children with early childhood caries. ${ }^{107}$ Higher frequency of sugar intake leads to increased risk and susceptibility to caries due to prolonged exposure to acidic conditions, regardless of the amount ingested.

\section{Acid erosion mechanisms}

Dental erosion can be defined as being the loss of hard tissues though dissolution by acids of nonbacterial origin or mechanical damage. When exposed to acid, teeth become softer as the HA is solubilized, and therefore, more susceptible to mechanical wear. The two chemical methods by which this can occur are either direct acid attack or chelation. ${ }^{57,74,90}$

When hydronium ions are formed from an acid in solution, they bind with carbonate or phosphate in HA, releasing the anions into solution in a form of chemical etching. Carbonate is more reactive than phosphate, and requires a lower concentration of hydronium to react with, and is therefore why $\mathrm{HA}$ is weaker with excess carbonate. ${ }^{57}$

Three phases of attack have been identified, based on the $\mathrm{pH}$ of the acid. ${ }^{108}$ Acids with $\mathrm{pH}<1$ can cause surface etching when exposed to teeth for very short time periods. Nanoscale surface softening occurs with short exposure at pH 2-4, but this does not extend to the macroscale..$^{70,109}$ The third and most common form of acid attack is through weak acid ( $\mathrm{pH}$ 4.5-6.9) subsurface dissolution. This along with bacteria can lead to the formation of carious lesions and as a result has been well studied.

Exposure to acids with $\mathrm{pH}>4$ is not a common biological occurrence. Emesis is the normal mechanics, whereby stomach acids can come into contact with the teeth. Some patients with the most severe and prolonged hyperemesis episodes, such as those with alcoholism, may subject their teeth to acids with a $\mathrm{pH}$ of $1 .{ }^{55}$ This is well below the demineralization $\mathrm{pH}$ and can cause surface etching, which is highly dangerous for teeth. Dentition in patients with intrinsic disease factors such as hyperemesis gravidarum or bulimia may be exposed to low $\mathrm{pH}$ acids regularly enough to cause nanoscale surface softening..$^{70,109,110}$ However, the weak acid dissolution pathway has many possible causes. Fruits commonly have carboxylic or citric acids. ${ }^{87,109}$ The hydronium ion formed by carboxylic acids readily binds with phosphate, forming phosphate cations. ${ }^{55,111}$ These cations can form a calcium acid chelation complex, debonding mineral ions in the surrounding lattice causing widespread demineralization. ${ }^{74}$ Alternatively and more rarely, these can remain in proximity to the HA layer, with minimal demineralization.
Carboxylic acids can also allow for attacks through chelation. Fruit acids such as citric acid $\left(\mathrm{C}_{6} \mathrm{H}_{8} \mathrm{O}_{7}\right)$ are commonly found examples of this. In citric acid, the $\mathrm{COOH}$ group is dissociated, forming $\mathrm{H}^{+}$for $\mathrm{H}_{3} \mathrm{O}^{+}$and allowing a $\mathrm{COO}^{-}$anion to cause calcium chelation. ${ }^{87}$ The direct acid attack, using hydronium ions, has already been described above. Two anions, however, are able to form a soluble chelate complex with three calcium ions. This is dependent on the dissolution strength of the anion relative to the bound calcium in HA and results in the formation of a chelate at $\mathrm{pH} 3.8-4$, the $\mathrm{pH}$ of fruit and fruit drinks. ${ }^{93}$ As the chelate is soluble, this can then be carried from the enamel surface, resulting in a net loss of mineral for the teeth. Although commonly found in fruits and soft drinks, citric acid is particularly damaging teeth, and it can act through two mechanisms to remove both phosphate and calcium from the HA. ${ }^{77,88}$ Carbonic acid behaves similarly to citric acid; however, the dissolution constant is lower ( $\mathrm{pKa}$ 3.6) compared with citric acid (pKa 6.4). Carbonic acid can disassociate to form both bicarbonate anions $\mathrm{HCO}_{3}^{-}$and orthocarbonic acid $\mathrm{C}(\mathrm{OH})_{4}$, which increases the risk of acid attack on teeth. ${ }^{57,112}$ The amount of carbonic acid added to carbonated ("fizzy") drinks is often too low to have significant effects.

Although the carbonic acid content may be low, the presence of phosphoric acid in soft drinks, especially cola products, is damaging to teeth. Phosphoric acid $\left(\mathrm{H}_{3} \mathrm{PO}_{4}\right)$ does not contain a carboxylic group but still attacks teeth through both the direct pathway and chelation. ${ }^{112,113}$ Two hydrogens disassociate from phosphoric acid, allowing two hydronium ions to be formed for direct acid attack. ${ }^{18,77}$ The remaining phosphate ion $\left(\mathrm{PO}_{4}{ }^{3-}\right)$ can chelate with calcium cations at ratio of $2: 3$, forming soluble calcium phosphate. Some hydrogen phosphate $\left(\mathrm{HPO}_{4}{ }^{2-}\right)$ is also formed that chelates with calcium cations in a 1:1 ratio. Both pathways occur at low $\mathrm{pH}$ ranges and contribute to demineralization with acidic and sparkling drinks; the effect of which is seen in Figure $1 .^{108,113}$

\section{Chemical erosion mechanisms}

When discussing tooth erosion, $\mathrm{pH}$ is important, but it is not necessarily the crucial factor. ${ }^{114,115}$ The routes of direct acidic attack have been seen at length and are well documented. Irrespective of the exact type of acid in a drink, a lower $\mathrm{pH}$ dissolves $\mathrm{HA}$ in enamel at a faster rate and more severely than would a higher $\mathrm{pH}$ acid drink. Chelation causes a destabilization of the HA surface at low pH, weakening the phosphate coordination bonds. ${ }^{60}$ Acid concentration in molarity should also be taken into consideration. Titratable acidity, the amount of alkali required to titrate the subject to 

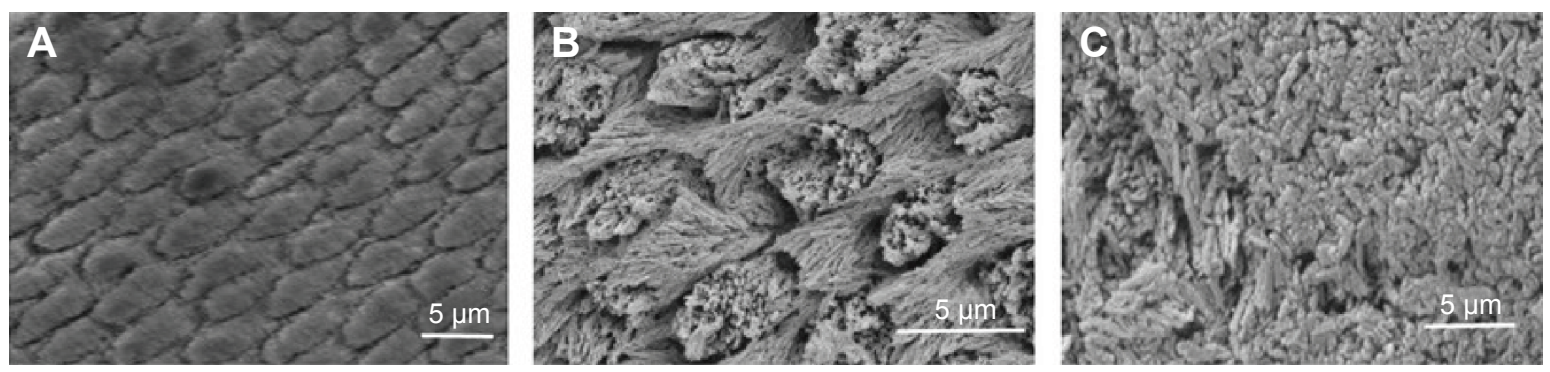

Figure I Scanning electron microscopic images showing (A) normal enamel, (B) enamel etched with phosphoric acid at the same concentration as found in drinks, and (C) the recrystallized HA after solubilization (edges of the image) compared to unetched HA (center of the image).

Abbreviation: HA, hydroxyapatite.

its natural value, has been used to measure the concentration of acids present in drinks. ${ }^{116}$ Although the $\mathrm{pH}$ ranges that can be tested using this method are often not found in commercial products, nor is the length of exposure relevant to drinking, titratable acidity remains a commonly tested value. ${ }^{117}$ While $\mathrm{pH}$ measures just the dissociated ions in a solution, which could form acids or alkalis, titratable acidity also measures the bound compounds giving a larger overview of the potential acidity of a solution. ${ }^{60,114,117}$ Although titratable acidity experiments often have experimental drawbacks, an increase in titratable acidity has been shown to be linked to an increase in enamel loss in model studies. ${ }^{80,118}$

Linked to titratable acidity is the undissociated acid concentration, a measure of the inactive acidity of a solution. This describes solute that does not contribute to the $\mathrm{pH}$ of a solution. ${ }^{115}$ These molecules are also uncharged, which allows for a localized increase in hydrogen ions once diffused into the HA. Acids that have a low pKa have an increased concentration of molecules in a disassociated form..$^{93}$ These hydrogen ions react with water to form hydronium ions, which are delivered to enamel. This high concentration of hydrogen ions favors dissolution of the enamel, at a layer known as the mineralization front. ${ }^{93}$ Short-term erosion sides have shown significant reduction in hydrogen when the disassociated value of acids was changed to favor higher $\mathrm{pH}$ levels. ${ }^{117}$ The $\mathrm{pH}$ remains the value that is most quoted for expositors to dietary acid over normal eating or drinking timescales.

The equilibrium constant for acid dissociation $(\mathrm{Ka})$ and its logarithmic value $(\mathrm{pKa})$ indicate the ratio of ionizedto-nonionized acid groups in aqueous solution. ${ }^{119}$ A solution with equal $\mathrm{pKa}$ and $\mathrm{pH}$ values will have $50 \%$ chelator anions and $50 \%$ disassociated acid in solution. ${ }^{60} \mathrm{pKa}$ values alter with environment, solvent, and structural changes. The pathway by which an acid is likely to attack HA in teeth can be predicted from the $\mathrm{pKa}$ value. A carboxylic acid with a low $\mathrm{pKa}$ value in water is likely to produce a high number of chelating ions, while a higher pKa value suggests direct hydrogen ion attack. ${ }^{60}$ Although citric acid has a low pKa value (3.1) in water compared with hydrochloric acid (-6.1), it does not mean that the carboxylic acids are not damaging. ${ }^{120} \mathrm{Ka}$ or pKa values cannot be used to directly measure the severity of an acid but is crucial in modeling other values. ${ }^{118}$

Although chemical and mechanical methods of erosion are often considered separately, models such as the differential buffering capacity (DBC) of an acid can predict the mechanical effects of acid demineralization. ${ }^{117,121} \mathrm{DBC}$ is measured as the gradient of a titration curve at a certain $\mathrm{pH}$ value and gives the concentration of acid required to lower the $\mathrm{pH}$ by $1 .{ }^{122}$ Acids with lower DBC values have been shown to have more severe effects on enamel for short-term exposure than higher DBC values. ${ }^{117,121}$ The $\mathrm{DBC}$ value of an acid is made up of the $\mathrm{pKa}$ and $\mathrm{pH}$ values and is therefore considered to be a more reliable marker of erosion properties over long-term exposure, when the $\mathrm{pH}$ range is relevant for dietary exposure. ${ }^{122}$

Temperature has a significant impact on the kinetics of dissolution. In the mouth, the ambient temperature is higher than room temperature, increasing the kinetic rate of reaction. ${ }^{68,110}$ The ions in solution, which impact the enamel causing dissolution, exceed the total energy required for the dissolution of the calcium. The results in a greater level of demineralization would occur at room temperature but is unavoidable due to physiological conditions. ${ }^{123}$

All these descriptors factor into the erosion of enamel by dietary acids. However, there is no conclusive study indicating which is more important or representative for dietary conditions.

\section{Remineralization}

This section covers both prevention and cure of demineralization that can be arrested or reversed particularly in its 
early stage. Saliva, fluoride therapy, diet control, and probiotic bacteria are described as preventive regimes for tooth demineralization. Dental composites containing different forms of calcium phosphates (CaPs) are discussed as potentially curative regime for tooth demineralization. The use of nanotechnology in preventive dentistry, as antibacterial nanotherapy and biomimetic remineralization for reversing an incipient caries or recurrent decay, was explained in details in the literature. ${ }^{124}$

\section{Saliva}

As mentioned above, saliva is considered one of the most important biological factors in dictating the intraoral neutralizing effects of acid exposure. Pathogenesis of dental erosion is directly related to the buffering capacity and rate of secretion of saliva. ${ }^{96}$ In addition to its cleansing and antibacterial action, ${ }^{125}$ saliva acts as a constant source for calcium and phosphate that helps in maintaining supersaturation with respect to tooth minerals, therefore inhibiting tooth demineralization during periods of low $\mathrm{pH}$, and they promote tooth remineralization when the $\mathrm{pH}$ returns to neutral state. Furthermore, when saliva secretion is stimulated, a rapid rise in $\mathrm{pH}$ to above neutrality occurs. As a result a complex of calcium phosphate and glycoprotein called salivary precipitin is formed. This complex is readily incorporated into dental plaque. Due to its high solubility of calcium phosphate in salivary proteins (eight to ten times higher than calcium phosphate in tooth), it serves as a sacrificial mineral that dissolves preferentially before tooth mineral, ie, reducing demineralization. It also acts as a source of calcium and phosphate ions that are required for remineralization of decalcified tooth. ${ }^{63,126}$

Saliva constantly delivers fluoride to the tooth surface; salivary fluoride is a key player in preventing tooth demineralization and enhancing remineralization ${ }^{125}$ as described in the "Fluoride therapy" section.

\section{Fluoride therapy}

Fluorination of teeth is encouraged; ${ }^{127}$ the most effective method of caries prevention is through the use of topical fluoride, such as toothpaste and varnish. The calcium in HA is displaced by fluorine, forming FAP, which has a much lower solubility than either the original or calcium-deficient HA. FAP forms a solid-state solution with the phosphaterich $\mathrm{HA}$, with a hydroxide being displaced. ${ }^{55,77}$ FAP has two main advantages over HA, and fluorine is often added to drinking water to encourage the conversion. ${ }^{127}$ First, fluoride acts as a catalyst, assisting in the remineralization enamel with phosphate ions dissolved in saliva. ${ }^{103,128}$ This can help to counteract any demineralization which has occurred. ${ }^{111}$ Second, the displacement of hydroxide with fluoride removes a weakness in HA to lactic acid; FAP $\left[\mathrm{Ca}_{10}\left(\mathrm{PO}_{4}\right)_{6} \mathrm{~F}_{2}\right]$ is not dissolved by this in the mouth. ${ }^{74,129,130}$ For the formation of FAP, for every two fluoride ions, ten calcium ions and six phosphate ions are required. Accordingly, the presence of inadequate calcium and phosphate can limit the remineralization process. Casein phosphopeptide-ACP (CPP-ACP) has been developed for this purpose. Aggregation of CPP with calcium phosphate forms clusters of ACP. This aggregation prevents the precipitation of calcium phosphate and hence results in a state of supersaturation with respect to enamel, thus preventing demineralization and enhancing remineralization. ${ }^{131}$ Some commercially available dental products contain both CPP-ACP and fluoride, and they are very effective remineralizing agents. ${ }^{132-134}$ Regardless of the significant effect of fluoride in preventing tooth demineralization, care as to not exceed the maximum recommended dose of fluoride is highly advised. Overconsumption of fluoride through fluoridated water/foods and/or supplements may lead to dental and/or skeletal fluorosis. Dental fluorosis is defined as mineralization defects of enamel, resulting from subsurface porosity below a well-mineralized surface zone. ${ }^{14}$

Since the recovery of plaque $\mathrm{pH}$ to a higher level than the critical $\mathrm{pH}$ plays a key role in remineralization process, addition of $1.5 \%$ arginine (insoluble calcium compound) to fluoride in tooth dentifrices was more effective in reducing tooth demineralization and progression of caries to cavitation than those containing fluoride alone. The arginine is broken down into ammonia by nonpathogenic arginolytic bacteria; ammonia helps in neutralizing plaque acid and maintaining the plaque biofilm on tooth surface in a healthy state. ${ }^{63,135,136}$

\section{Diet control and oral hygiene instructions}

Additionally, dietary advice, oral hygiene instruction, and application of fissure sealants are still used as further preventive regime to dental caries in both high- and low-risk individuals. In most recent studies, it was shown that the use of nonfermentable sugars in chewing gum, such as xylitol, was seen to inhibit the effect of S. mutans; however, more conclusive evidence is yet to be achieved.

\section{Probiotic bacteria}

Probiotic bacteria, defined as "live microorganisms which, when administered in adequate amounts, confer a health benefit on the host" (WHO), are commonly suggested candidates 
for bacteriotherapy. ${ }^{137}$ The word probiotics means "for life", and this is either naturally occurring or genetically engineered bacterial strains that can be used for intervention. ${ }^{137}$ Examples of probiotics that have the ability to confer oral health benefits for the host include Lactobacillus (eg, salvarius, ${ }^{138}$ reuteri, ${ }^{139}$ and rhamnosus ${ }^{140}$ ) and Bifidobacterium that are part of normal oral flora. ${ }^{140-142}$ They can be used as biotherapy for prevention or treatment of dental caries and periodontal diseases ${ }^{143}$ by reducing the number of pathogenic bacteria (S. mutans $)^{143,144}$ or inhibiting the expression of $S$. mutans virulence genes, for example, GtfB and $\operatorname{Lux} S^{140,145}$ and therefore alter or reduce biofilm formation. ${ }^{138}$

For administration of probiotic strains, several appropriate vehicles are available; they vary from dairy products, ice cream and curds, ${ }^{146}$ oral thin film,,${ }^{147}$ tablets, ${ }^{139,148}$ and lozenges (eg, PerioBalance). ${ }^{149}$ The use of probiotic products found a potential use as alternative strategy for displacing pathogenic bacteria with probiotic microorganism and can therefore be exploited for the prevention of enamel demineralization. ${ }^{146}$

Another avenue to reduce the cariogenicity of $S$. mutans is the generation of strains without the open reading frame of lactate hydrogenase. ${ }^{150}$

\section{Electrically assisted enhanced remineralization}

A new technology that has been developed by Reminova $\operatorname{Ltd}^{151}$ relies on the use of an electric current to reverse tooth decay by boosting remineralization. The use of tiny electric current of few microamperes that cannot be felt by the patient pushes the minerals into the tooth to repair the clean defect. This process requires no injection, no drilling of tooth, and no filling materials and triggers the remineralization from the deeper portion of the lesion. The development of a model ready to use by dentists from the prototype device developed by Reminova Ltd is currently under investigation. ${ }^{151}$

\section{Dental composites with remineralizing action}

Resin-based composites have been used as dental filling materials for $>50$ years. ${ }^{152}$ These materials have evolved throughout the years. The most important changes have involved the reinforcing fillers to improve the mechanical properties, polishability, and wear resistance. Recently, the focus has shifted to equipping composite systems with remineralizing and antibacterial properties. Various forms of calcium phosphates $(\mathrm{CaP})$ have been incorporated into resin-based composites to provide mineral release that could potentially remineralize the tooth structure. This section provides an overview on the development of potentially remineralizing composites for tooth repair that have recently been introduced.

Calcium phosphates in different forms have been studied as fillers to make mineral releasing dental composites. This includes ACP, HA, tetracalcium phosphate (TTCP), dicalcium phosphate (DCP) anhydrous, and mono-, di-, and TCPs. These calcium phosphate fillers partially replaced the reinforcing fillers. Unfortunately, this can compromise composite mechanical properties.

\section{Composites containing ACP}

ACP has been evaluated as filler for dental composites and adhesives. Skrtic et al ${ }^{153-155}$ has introduced composite materials containing ACP, which release significant amount of calcium and phosphate ions. It was demonstrated that the remineralizing potential of ACP was enhanced through its hybridization with silicon or zirconium elements. Adding these elements to ACP increased the time of mineral ion release through their ability to slow down the intracomposite ACP to HA conversion. ${ }^{156,157}$ Mineral ion release from ACP composites was shown to efficiently restore the mineral lost from enamel surfaces following acid attack. ${ }^{158,159}$ Another study has incorporated ACP into a composite adhesive system. The ACP was shown to infiltrate the dentinal tubules without causing negative effect to bond strength. ${ }^{160}$

Compared with glass or ceramic-only filled composites, the ACP-filled composites are more hydrophilic and biodegradable. In addition, they exhibit inferior mechanical properties and durability. ${ }^{161} \mathrm{ACP}$ particles aggregation, poor interfacial interaction with matrix, and excessive water sorption contribute to compromising the mechanical properties. ${ }^{155,162,163}$ Mechanical milling reduced the particles size of ACP-zirconium fillers to $\sim 20 \mu \mathrm{m}$, providing more homogeneous filler distribution and a reduction in voids formation was obtained. Biaxial flexural strength was, therefore, increased from 50 to $75 \mathrm{MPa} .{ }^{161,164-166}$ This is, however, still lower than the strength of commercial dental composites (100-180 MPa), restricting the use of ACPfilled composites as potential direct dental-filling materials. ${ }^{167}$ A recent study showed that $120 \mathrm{MPa}$ flexural strength could be obtained if the mass fraction of ACP was kept at $10 \mathrm{wt} \%$. However, this significantly reduced the amount of calcium and phosphate ions that could be released. ${ }^{168}$

\section{Composites containing HA}

Coupling agent treatment of calcium phosphate fillers with citric acid, acrylic acid, or methacrylic acid improved the flexural strength of composites containing HA. ${ }^{169,170}$ However, $\gamma$-methacryloxypropyltrimethoxysilane coupling agent 
had no effect on strength. ${ }^{171}$ Microscopic HA fillers provided higher strength than nanoscopic fillers. ${ }^{169,170,172}$ It was also reported that HA fillers in the form of whiskers further enhanced flexural strength. ${ }^{173,174}$

Water sorption of resin-based composites containing silane coupling agent-treated and -untreated HA fillers was consistent with a diffusion-controlled process. Incorporation of HA reduced the water uptake, and this decreased further upon silane treating of HA fillers, ${ }^{175}$ which subsequently led to deterioration in $\mathrm{CaP}$ release.

In an attempt to improve the mechanical properties, small fraction ( $3 \mathrm{wt} \%$ ) of HA filler were impregnated into composites. This low mass fraction of HA was well dispersed, leading to increase in the flexural strength up to $120 \mathrm{MPa}$. Raising mass fraction of $\mathrm{HA}$ to $10 \mathrm{wt} \%$ caused to decrease strength to $95 \mathrm{MPa}$ due to the formation of aggregates of HA that served as a defect site. ${ }^{176}$

\section{Composites containing TTCPs}

Recently, TTCP particles were investigated as potentially remineralizing fillers for dental composites. Upon addition of TTCP, the mechanical properties of the composites decreased dramatically. Replacing $50 \%$ of TTCP by silicon nitride whiskers increased the strength of the composites from 50 to $100 \mathrm{MPa}$. Calcium and phosphate ion release, however, was decreased by an order of magnitude. ${ }^{177}$ Another study showed that flexural strength can reach $80 \mathrm{MPa}$ for composites filled with $40 \mathrm{wt} \%$ TTCP. This has increased further upon addition of an antibacterial agent. ${ }^{178}$

\section{Composites containing mono-, di-, and tricalcium phosphates}

Calcium phosphates in the form of monocalcium phosphate (MCPM), DCP, and TCP were also incorporated into dental composites materials. The solubility of these forms of calcium phosphate differs significantly. The mineral ion release from MCPM composite was shown to be dependent on the amount of MCPM added to the formulation. Replacing the MCPM with reinforcing whiskers was shown again to improve mechanical properties but dramatically decrease calcium and phosphate release. ${ }^{179}$ Replacing MCPM with less soluble DCP enhanced the strength but significantly reduced mineral ions release. ${ }^{180}$ A study showed that by decreasing the particle size of DCP fillers to $\sim 110 \mathrm{~nm}$, the amount of mineral ions release can be significantly increased. ${ }^{181}$ It has also confirmed that replacing DCP with silicon nitride whiskers enhanced the strength but at the expense of the mineral ion release. In addition, incorporating whiskers in the composite formulations compromised the optical properties preventing light cure feasibility.

TCP has been added together with MCPM to enable more control on the latter dissolution and composite water sorption. ${ }^{182-185}$ Highly soluble MCPM on the surface of the composite dissolved but at the core it reacted with $\beta$-TCP to form less soluble brushite (DCP dihydrate). Partial replacement of calcium and phosphate with reinforcing opaque fillers improved the strength but these again compromised the mineral ion release and optical properties. ${ }^{182}$ A recent study has introduced light-cured composites containing both MCPM and TCP with strength within the range expected for commercial composites. ${ }^{183,184}$ HA precipitation at the surfaces of these composites was used to evaluate the remineralization potential of these materials. These HA layers were formed of calcium and phosphate ions released from within the composite samples. ${ }^{184}$ Although these results are promising, the ability of these composites to remineralize the demineralized dentine has yet to be demonstrated.

\section{Demineralization-remineralization dynamics in bone}

Bone remodeling is a physiologic process that continues within discrete sites following cessation of skeletal growth. During remodeling, packets of bone are laid down and turned over in order to facilitate the repair of damaged older bone. Osteoclasts resorb bone, and these resorption lacunae are subsequently filled with new bone matrix deposited by osteoblasts. As newly formed bone accumulates mineral with time, the most recently deposited bone will generally be less mineralized than bone deposited months or years earlier. Regions with high turnover, containing many newly formed osteons, generally display lower average mineralization than areas of low turnover. During secondary mineralization, the mineral content of an individual unit continuously increases with time (referred to as the mineralization law), with a steep slope in the beginning and a significant reduction in the slope afterward. ${ }^{186}$ The weight or volume fraction of mineral in the bone matrix is measured spatially by methods such as plain radiography, dual-energy X-ray absorptiometry, Faxitron X-ray microradiography, synchrotron, microcomputed tomography, and quantitative backscattered electron microscopy.

Bone remodeling is essential for the required tooth movement during orthodontic treatment. The interaction between the receptor activator of nuclear factor $\mathrm{KB}$ (RANK) that is expressed on osteoclast precursor cells, its ligand (RANKL) 
that is expressed on osteoblast cells, and osteoprotegerin is responsible for the regulation of bone remodeling process. Binding of RANKL to RANK results in differentiation of precursor osteoclast cells to mature osteoclasts. Osteoprotegerin competes with RANK for RANKL binding and inhibits osteoclast differentiation. The balance of these trimolecular control factors maintains physiologic bone remodeling. ${ }^{187}$

Any imbalance between bone formation and resorption has undesirable consequences.

\section{Demineralization (hyper- and hypomineralization)}

The mineralization density at the tissue level reflects the contribution of all osteons with different degrees of mineralization and disruptions in the physiological and biochemical processes that regulate the deposition and removal of calcium apatite in a tissue may be caused by age, ${ }^{188}$ disease, and drug treatment. ${ }^{189}$ Small increases in mineralization lead to relatively large increases in the strength of bone, although levels $\sim>66 \%$ mineralization have been shown to lead to brittleness and a reduction in bone strength. ${ }^{190}$

Hypermineralization and hypomineralization are deviations that occur within the mineral content of fully mineralized bone. Only a pathologically altered organic matrix and/or abnormalities in crystal size and shape can lead to a hypermineralization, a mineralization density exceeding that of fully mineralized normal bone matrix. In contrast, hypomineralization results when the organic matrix is not fully mineralized due to a lack of time for secondary mineralization and/or by a pathologically altered bone matrix, affecting normal mineralization kinetics. ${ }^{189}$ Bone diseases such as rickets and osteoporosis cause a significant reduction in bone mineralization and bone mineral density, which lead to functional consequences in terms of increased fracture risk and skeletal deformity, respectively. ${ }^{188}$ Mild primary hyperthyroidism is characterized by abnormally elevated parathyroid hormone serum levels accompanied by hypercalcemia, which also results in a low bone mineralization density that is thought to be due to an increased bone turnover and bone formation rate. ${ }^{186}$

Osteogenesis imperfecta is a genetic disorder associated with increased bone fragility. Studies indicate a shift toward a higher mineralization density of bone tissue, only marginally exceeding that of normal adults. ${ }^{191}$ Weber et al ${ }^{192}$ suggested that the higher mineral content was not exclusively due to an altered collagen structure but may also be caused by an accelerated mineralization process. Alterations in bone mineral density have also been measured in male osteoporosis, idiopathic osteoporosis, patients with collagen I polymorphisms, ${ }^{193}$ osteomalacia, ${ }^{194}$ hypophosphatemia, Paget's disease, Bruck's syndrome, myopathy, renal osteodystrophy, ${ }^{195}$ and liver transplantation. ${ }^{196}$ All showed a shift to lower mineralization density, while pycnodysostosis ${ }^{197}$ hypoparathyroidism, osteopetrosis, and osteonecrosis all led to an increased mineralization density. ${ }^{189}$

\section{Remineralization}

Some drugs have been developed to either reduce bone resorption (eg, bisphosphonates ${ }^{198}$ ) or promote bone formation (hormonal replacement, ${ }^{199}$ calcium, and vitamin D supplements). Combination and sequential treatment using both bone formation stimulator and bone resorption inhibitors have been attempted. Combination treatment using both bone resorption inhibitors and bone-formation stimulators has not showed any additional benefit over the use of each medication alone. The use of bone-formation stimulators is independent on the previous use of bone resorption inhibitor. The use of bone resorption inhibitors; however, maintains the benefit of the former bone formation stimulator. ${ }^{199}$ Generally, serious side effects, however, have now been associated with the extensive use of these drugs. ${ }^{198,200,201}$ This, however, is not the main focus of this review. Only the materials with remineralizing action will be covered in details.

Bone cements/composites with remineralizing action Poly(methylmethacrylate) (PMMA) has been widely used in orthopedic surgeries as anchoring agent in hip and knee replacement to repair vertebral fractures and skull defects. ${ }^{202}$ To overcome the disadvantages of conventional PMMA cements such as lack of adhesion to bone and heat generation during polymerization, calcium phosphate cements and polymeric cements with mineralizing fillers have been investigated as alternatives.

Various forms of calcium phosphates have been studied as bone cements due to their excellent biocompatibility. ${ }^{203}$ The main shortcomings of these materials, however, are the mechanical properties. These properties were improved through formation of polymer composites containing calcium phosphate. The polymer matrix reinforced with glass or ceramic fillers and contain $\mathrm{CaP}$ fillers can potentially provide remineralizing materials with good mechanical properties. This includes calcium phosphates in the forms of HA, $\beta$-TCP, and biphasic calcium phosphate. 


\section{Nondegradable cements/composites}

Cements/composites containing HA. HA was used as filler in self-curing two paste bone cements. Upon immersion in simulated body fluid, the materials were shown to form an apatite layer. This feature has been associated with bone bonding ability. ${ }^{202}$ Bioactive glass, HA, and $\beta$-TCP have also been used to develop bone cements that have been reported to exhibit bone-bonding properties. ${ }^{204,205}$ Enhanced cellular activity has been associated with increased levels of HA fillers in the composite materials. ${ }^{206}$ Ultimate tensile strength, however, decreased with increased HA content.

A combination of strontium and HA containing bone cement was reported to provide superior bone-bonding strength to that with conventional PMMA cement. ${ }^{207}$ Addition of HA to PMMA also enhanced the biocompatibility and osteoconductivity of the cement. ${ }^{208}$

Cements/composites containing $\beta$-TCP. Composite bone cements containing $\beta$-TCP were also reported to be biocompatible, and osteoconduction was attained within 4 weeks of direct contact with bone. ${ }^{209}$ A study showed that resin composite bone cements contain either bioactive glass ceramics or $\beta$-TCP that induces bone formation at the interface. ${ }^{210}$ However, the mechanical properties of the former were higher than the latter.

\section{Biodegradable calcium and phosphate cements}

Calcium and phosphate cements have been investigated as synthetic materials to fill bone defects and cavities due to their excellent biocompatibility and osteoconductivity. ${ }^{203,211}$ The formation of these materials is activated by mixing various calcium phosphate phases with a liquid phase at a specific $\mathrm{pH}$. The $\mathrm{pH}$ of the chemical reaction dictates the type of final product; HA forms at $\mathrm{pH}>4.2$ or brushite at $\mathrm{pH}<4.2 .^{211,212}$ Unlike brushite $\left(\mathrm{CaHPO}_{4} \cdot 2 \mathrm{H}_{2} \mathrm{O}\right)$, HA-based cements were shown to have poor solubility at a physiological $\mathrm{pH} .^{213}$ Calcium and phosphate cements are brittle with low strength and can only be used in nonload-bearing applications. ${ }^{211}$

\section{Apatite cements}

Commercially available apatite cements were developed using different chemical formulations containing more than one type of calcium phosphates such as $\alpha$-TCP, MCPM, and TTCP. Precipitated HA or calcium-deficient HA can be formed by hydrolyzing calcium phosphate or by mixing two calcium phosphate powders with $\mathrm{Ca}: \mathrm{P}$ ratio lower than the stoichiometric ratio for $\mathrm{HA}(\mathrm{Ca}: \mathrm{P}=1.67) .{ }^{214}$ These materials were shown to have poor solubility and subsequently reduced chances of replacement with natural bone tissues.

\section{Brushite cement}

These cements have been developed to take advantage of their high solubility in order to increase the amount of regenerated tissues. ${ }^{211}$ In a physiological condition, brushite dissolves providing calcium and phosphates ions, in addition, to their high biocompatibility and osteoconductivity. ${ }^{215}$ Mechanical properties of brushite cements, however, are lower than apatite cements. Today, research is focused on improving the overall performance of brushite by balancing resorbability and mechanical properties.

Throughout this review, the mechanisms of demineralization-remineralization in both teeth and bone as well as therapies that boost remineralization have been thoroughly discussed. Understanding these processes is also important for the innovation and development of scaffolds or implant surfaces that are able to stimulate mineralization or osseointegration. The interaction of biomaterials with host tissues is an important issue that has to be addressed during designing scaffolds or implants for biomedical use. The topography, chemical, and mechanical properties of the materials from which scaffolds or implants has been made have fundamental influence on the host response. Some innovative approaches seem to be promising in designing scaffolds or implants with topographical features that favor osteogenic differentiation. Electrospinning, rapid prototyping, ${ }^{216}$ and two-photon polymerization ${ }^{217}$ could be promising in designing scaffolds with biomimetic architecture, required for nutrient supply and diffusion, as well as with instructive surface properties required for directing cells into the proper lineage. Osteoprints, bioinspired two-photon polymerized 3D trabecular-like structures, deeply influenced cellular behavior, enhanced osteogenic differentiation, and increased HA production. ${ }^{217}$ Direct laser writing/atomic layer deposition, ${ }^{218}$ lithography, ionic implantation, anodization, ${ }^{219}$ radio frequency plasma treatments, ${ }^{220-223}$ and surface treatment (eg, glow discharge, acid etching, or UV irradiation) ${ }^{224}$ have been used to tailor implants' surface topography in favor of osseointegration. ${ }^{225,226}$ Controlling the surface topography at nanoscale level or chemistry of scaffolds or implants could influence cells spreading ${ }^{222}$ and differentiation. ${ }^{220,221}$ Modification of chitosan scaffolds with barium titanate nanoparticles or strontium phosphate favored the osteogenic differentiation of mesenchymal stem cells..$^{227,228}$ Nanoarrays from tantala improved adhesion, proliferation, and differentiation of osteoblast cells on implant surface. ${ }^{229}$ Biofunctionalization, that is, immobilization of specific active biomolecules known with their effective role on osteogensis on the surface of scaffolds or implants, has also been attempted to improve their long-term acceptance. ${ }^{230}$ Examples include ECM proteins, ${ }^{231}$ adhesion 
molecule (arginyl-glycyl-aspartic), ${ }^{232}$ and bone morphogenic protein. $^{233}$

\section{Concluding remarks and future prospects}

Demineralization-remineralization is a dynamic process, and there is always a battle between them. Both processes can occur on the hard tissues surface to some extent. They therefore have an impact on the health of hard tissues, and the surrounding environment plays a key role in determining which process wins the battle. Therefore, the main aim would be maintaining the environment that prevents demineralization but encourages remineralization.

The understanding of the process of demineralization and remineralization in teeth is very well understood. However, despite efforts by researchers and clinicians, maintaining a good oral and dental health throughout patients' life remained a big challenge. The constant change in diet associated with the more and more widespread accessibility of fizzing sugary drinks is putting pressure on the whole dental profession to safeguard good oral and dental health, even in wealthy country. A University College London survey at the London 2012 Olympic Games found that 18\% of athletes said that their oral health had a negative impact on their performance and $46.5 \%$ had not been to the dentist in the past year. In terms of dentistry, the challenge in the next decade is to either promote a change in the habits of population or for scientists to develop new products that may counter the demineralization process that results from the consumption of these fizzing sugary drinks. The more and more widespread prevalence of dental caries is a direct consequence of this growing population behavior, and it will become ever more important to involve the public and patients to devise strategies to overcome this growing health burden. The wider use of gums that promote salivary release or neutralized the mouth $\mathrm{pH}$ is also explored and would help toward building sufficient sacrificial amorphous enamel layer. The development of smart restorative materials has made tremendous progress in the field of dentistry, but their translation to market is slower than in medicine, maybe due to the reticence of dental practitioners to adopt these novel materials. It is likely that in the next few years, new generation of restorative materials will become accessible that will make traditional mechanical drilling redundant. The challenge for bone remains to find long-term solution to conditions associated with persistent bone loss such as osteoporosis. Research in this area is still very active, but it has yet to find a sustainable approach to reverse the slow resorption of bone, which consequently may fracture and impact greatly upon the patients' quality of life. Similarly, the development of smart materials in dentistry, a similar approach exists for bone with the genesis of bone cements that are becoming available for repairing spinal cord injuries, for example. Unlike dentistry, the causative effects of bone demineralization are not patients' behavior driven except for reduced physical activity. Coupling these strategies for earlier diagnostics of bone fragility or dental demineralization would greatly enhance patients' recovery. Thus, research is currently being carried out across the world to offer new diagnostic tools for clinical use to help with the early detection. Few of these tools, such as Bio-Dent and dental optical coherence tomography, are currently on the market, and it will take a few more years for their acceptance by clinical colleagues. Ultimately, although scientists and/or clinicians may discover new understanding, develop new technologies, and products, it is still the responsibility of the patients to adapt their personal behaviors to minimize the risk factors associated with bone or dental surface loss.

\section{Disclosure}

The authors report no conflicts of interest in this work.

\section{References}

1. Gelse K, Poschl E, Aigner T. Collagens-structure, function, and biosynthesis. Adv Drug Deliv Rev. 2003;55(12):1531-1546.

2. Lin C, Douglas WH, Erlandsen SL. Scanning electron microscopy of type I collagen at the dentin-enamel junction of human teeth. $J$ Histochem Cytochem. 1993;41(3):381-388.

3. Nanci A. Ten Cate's Oral Histology: Development, Structure, and Function. Maryland Heights, MO: Mosby; 2008.

4. Vallet-Regí M, González-Calbet JM. Calcium phosphates as substitution of bone tissues. Prog Solid State Chem. 2004;32(1-2):1-31.

5. Beniash E. Biominerals-hierarchical nanocomposites: the example of bone wires. Nanomed Nanobiotechnol. 2011;3(1):47-69.

6. Boskey A, Young M, Kilts T, Verdelis K. Variation in mineral properties in normal and mutant bones and teeth. Cells Tissues Organs. 2005;181(3-4):144-153.

7. Duailibi MT, Duailibi SE, Young CS, Bartlett JD, Vacanti JP, Yelick PC. Bioengineered teeth from cultured rat tooth bud cells. J Dent Res. 2004;83(7):523-528.

8. Herring SW, Ochareon P. Bone - special problems of the craniofacial region. Orthod Craniofac Res. 2005;8(3):174-182.

9. Nudelman F, Pieterse K, George A, et al. The role of collagen in bone apatite formation in the presence of hydroxyapatite nucleation inhibitors. Nat Mater. 2010;9(12):1004-1009.

10. Dorozhkin S, Epple M. Biological and medical significance of calcium phosphates. Angew Chem Int Ed Engl. 2002;41(17):3130-3146.

11. Hart S, Hart T. Disorders of human dentin. Cells Tissues Organs. 2007;186(1):70-77.

12. Sasagawa I. Fine structure of the cap enameloid and of the dental epithelial cells during enameloid mineralisation and early maturation stages in the tilapia, a teleost. J Anat. 1997;190(Pt 4):589-600.

13. Felszeghy S, Holló K, Módis L, Lammi M. Type X collagen in human enamel development: a possible role in mineralization. Acta Odontol Scand. 2000;58(4):171-176. 
14. Robinson C, Connell S, Kirkham J, Brookes S, Shore R, Smith M. The effect of fluoride on the developing tooth. Caries Res. 2004;38(3): 268-276.

15. Eastoe J. Enamel protein chemistry - past present and future. J Dent Res. 1979;58(Spec Issue B):753-764.

16. Weidmann S, Eyre D. Amino acid composition of enamel protein in the fully developed human tooth. Caries Res. 1967;1(4):349-355.

17. Barron M, McDonnell S, Mackie I, Dixon M. Hereditary dentine disorders: dentinogenesis imperfecta and dentine dysplasia. Orphanet $J$ Rare Dis. 2008;3:31.

18. Zheng X, Hu J, Chen Y, Zhu Y, Chen H. AFM study of the effects of collagenase and its inhibitors on dentine collagen fibrils. J Dent. 2012;40(2):163-171.

19. Landis WJ, Song MJ, Leith A, McEwen L, McEwen BF. Mineral and organic matrix interaction in normally calcifying tendon visualized in 3 dimensions by high-voltage electron-microscopic tomography and graphic image-reconstruction. J Struct Biol. 1993;110(1):39-54.

20. Abou Neel EA, Bozec L, Knowles JC, et al. Collagen - emerging collagen based therapies hit the patient. Adv Drug Deliv Rev. 2013;65(4): 429-456.

21. Birk D, Silver F. Collagen fibrillogenesis in vitro: comparison of type I, II and II. Arch Biochem Biophys. 1984;235(1):178-185.

22. Martinez E, da Silva L, Furuse C, de Araújo N, de Araújo V. Dentin matrix protein 1 (DMP1) expression in developing human teeth. Braz Dent J. 2009;20(5):365-369.

23. Goldberg M, Kulkarni AB, Young M, Boskey A. Dentin: structure, composition and mineralization: the role of dentin ECM in dentin formation and mineralization. Front Biosci (Elite Ed). 2011;3:711-735.

24. Bevelander G, Nakahara $H$. The formation and mineralization of dentin. Anat Rec. 2005;156(3):303-324.

25. Kerebel B, Daculsi G, Kerebel L. Ultrastructural studies of enamel crystallites. J Dent Res. 1979;58(Spec Issue B):844-851.

26. Meckel A, Griebstein W, Neal R. Structure of mature human dental enamel as observed by electron microscopy. Arch Oral Biol. 1965;10(5): 775-783.

27. Bartlett JD. Dental enamel development: proteinases and their enamel matrix substrates. ISRN Dent. 2013;2013:684607.

28. Orgel J, San Antonio J, Antipova O. Molecular and structural mapping of collagen fibril interactions. Connect Tiss Res. 2011;52(1):2-17.

29. Robinson R, Watson M. Collagen-crystal relationships in bone as seen in the electron microscope. Anat Rec. 1952;114(3):383-409.

30. Nudelman F, Lausch A, Sommerdijk A, Sone E. In vitro models of collagen biomineralization. J Struct Biol. 2013;183(2):258-269.

31. Olszta MJ, Cheng X, Jee SS, et al. Bone structure and formation: a new perspective. Mater Sci Eng R. 2007;58:77-116.

32. Silver F, Landis W. Deposition of apatite in collagenous extracellular matrices: identification of possible nucleation sites on type I collagen. Conn Tis Res. 2011;52(3):242-252.

33. Wang Y, Azaïs T, Robin M, et al. The predominant role of collagen in the nucleation, growth, structure and orientation of bone apatite. Nat Mater. 2012;11(8):724-733.

34. Landis W, Jacquet R. Association of calcium and phosphate ions with collagen in the mineralization of veterbrate tissues. Calcif Tis Int. 2013; 93(4):329-337.

35. Veis A, Dorvee J. Biomineralization mechanisms: a new paradigm for crystal nucleation in organic matrices. Calcif Tissue Int. 2013;93(4): 307-315.

36. Urry D. On the molecular basis for vascular calcification. Perspect Biol Med. 1974;18(1):68-84.

37. Westenfeld R, Schafer C, Kruger T, et al. Fetuin-A protects against atherosclerotic calcification in CKD. J Am Soc Nephrol. 2009;20(6): 1264-1274.

38. Beniash E, Metzler R, Lam R, Gilbert P. Transient amorphous calcium phosphate in forming enamel. J Struct Biol. 2009;166(2):133-143.
39. Rey C, Combes C, Drouet C, Glimcher M. Bone mineral: update on chemical composition and structure. Osteoporos Int. 2009;20(6): 1013-1021.

40. Dey A, Bomans P, Muller F, et al. The role of prenucleation clusters in surface-induced calcium phosphate crystallization. Nat Mater. 2010; 9(12):1010-1014

41. Pouget E, Bomans P, Goos J, Frederik PM, de With G, Sommerdijk $\mathrm{N}$. The initial stages of template-controlled $\mathrm{CaCO}_{3}$ formation revealed by cryo-TEM. Science. 2009;323(5920):1455-1458.

42. Hunter G, Hauschka P, Poole A, Rosenberg L, Goldberg H. Nucleation and inhibition of hydroxyapatite formation by mineralized tissue proteins. Biochem J. 1996;317(Pt 1):59-64.

43. Qiu S, Wierzbicki A, Orme C, et al. Molecular modulation of calcium oxalate crystallization by osteopontin and citrate. Proc Natl Acad Sci US A. 2004;101(7):1811-1815.

44. Murshed M, McKee M. Molecular determinants of extracellular matrix mineralization in bone and blood vessels. Curr Opin Nephrol Hypertens. 2010;19(4):359-365.

45. Hessle L, Johnson K, Anderson H, et al. Tissue-nonspecific alkaline phosphatase and plasma cell membrane glycoprotein-1 are central antagonistic regulators of bone mineralization. Proc Natl Acad Sci US A. 2002;99(14):9445-9449.

46. Alliston T. Biological regulation of bone quality. Curr Osteoporos Rep. 2014;12(3):366-375.

47. Ho A, Johnson M, Kingsley D. Role of the mouse ank gene in control of tissue calcification and arthritis. Science. 2000;289(5477):265-270.

48. Bonnucci E. Fine structure of early cartilage calcification. J Ultra Res. 1967;20(1):33-50.

49. Anderson H, Matsuzawa T, Sajdera S, Ali S. Membranous particles in calcifying cartilage matrix. Trans N Y Acad Sci. 1970;32(5):619-630.

50. Orimo $H$. The mechanism of mineralization and the role of alkaline phosphatase in health and disease. J Nippon Med Sch. 2010;77(1):4-12.

51. Addison W, Azari F, Sorenson E, Kaartinen M, McKee M. Pyrophosphate inhibits mineralization of osteoblast cultures by binding to mineral, upregulating osteopontin and inhibiting alkaline phosphatase activity. J Biol Chem. 2007;282(21):15872-15883.

52. Mahamid J, Sharir A, Gur D, Zelzer E, Addadi L. Bone mineralization proceeds through intracellular calcium phosphate loaded vesicles: a cryo electron microscopy study. J Strut Biol. 2011;174(3):527-535.

53. Ma J, Johns R, Stafford R. Americans are not meeting current calcium recommendations. Am J Clin Nutr. 2007;85(5):1361-1366.

54. Currey J. The mechanical consequences of variation in the mineral content of bone. J Biomech. 1969;2(1):1-11.

55. Almeida e Silve JS, Baratieri L, Araujo E, Widmer N. Dental erosion: understanding this pervasive condition. J Esthet Restor Dent. 2011; 23(4):205-216.

56. Braly A, Darnell L, Mann A, Teaford M, Weihs T. The effect of prism orientation on the indentation testing of human molar enamel. Arch Oral Biol. 2007;52(9):856-860.

57. Wiegand A, Attin T. Occupational dental erosion from exposure to acids - a review. Occup Med (Lond). 2007;57(3):169-176.

58. LeGeros R. Calcium phosphates in enamel, dentine and bone. In: Myres H, editor. Calcium Phosphates in Oral Biology. 15th ed. Basel: Karger; 1991:108-129.

59. Ren YF. Dental erosion: etiology, diagnosis and prevention. Dental Hygenist. 2011:75-84.

60. Featherstone JD, Lussi A. Understanding the chemistry of dental erosion. Monogr Oral Sci. 2006;20:66-76.

61. Leventouri T, Antonakos A, Kyriacou A, Venturelli R, Liarokapis E, Perdikatsis V. Crystal structure studies of human dental apatite as a function of age. Int J Biomater. 2009;2009:698547.

62. Hara A, Zero D. The caries environment: saliva, pellicle, diet, and hard tissue ultrastructure. Dent Clin North Am. 2010;54(3):455-467.

63. Cummins D. The development and validation of a new technology, based upon $1.5 \%$ arginine, an insoluble calcium compound and fluoride, for everyday use in the prevention and treatment of dental caries. J Dent. 2013;41(2):S1-S11. 
64. Higham S [webpage on the Internet]. Caries Process and Prevention Strategies: Demineralization/Remineralization. Available from: http://www.dentalcare.com/media/en-US/education/ce372/ce372.pdf. Accessed June 23, 2016.

65. Ji W, Yang F, Ma J, et al. Biomaterials Incorporation of stromal cellderived factor-1 a in PCL/gelatin electrospun membranes for guided bone regeneration. Biomaterials. 2013;34(3):735-745.

66. Shepherd TJ, Dirks W, Manmee C, et al. Reconstructing the life-time lead exposure in children using dentine in deciduous teeth. Sci Total Environ. 2012;425:214-222.

67. Vanderby R, Provenzano PP. Collagen in connective tissue: from tendon to bone. J Biomech. 2003;36(10):1523-1527.

68. Burr DB. Anatomy and physiology of the mineralized tissues: role in the pathogenesis of osteoarthrosis. Osteoarthr Cartil. 2004 12(A):20-30.

69. Scaramucci T, Carvalho JC, Hara AT, Zero DT. Causes of Dental Erosion: Extrinsic Factors. Berlin: Springer International Publishing; 2015:69-96.

70. Barbour ME, Finke M, Parker DM, Hughes JA, Allen GC, Addy M. The relationship between enamel softening and erosion caused by soft drinks at a range of temperatures. J Dent. 2006;34(3):207-213.

71. Meredith N, Sherriff M, Setchell DJ, Swanson SA. Measurement of the microhardness and young's modulus of human enamel and dentine using an indentation technique. Arch Oral Biol. 1996;41(6):539-545.

72. Kwang S, Abbott P. The presence and distribution of bacteria in dentinal tubules of root filled teeth. Int Endod J. 2014;47(6):600-610.

73. Scaramucci T, Carvalho JC, Hara AT, Zero DT. Causes of Dental Erosion: Intrinsic Factors. Berlin: Springer International Publishing; 2015:35-67.

74. Lussi A, Jaeggi T. Erosion - diagnosis and risk factors. Clin Oral Investig. 2008;12(S1):5-13.

75. Youravong N, Teanpaisan R, Norén JG, et al. Chemical composition of enamel and dentine in primary teeth in children from Thailand exposed to lead. Sci Total Environ. 2008;389(2-3):253-258.

76. Wheater P, Burkitt H, Daniels V. Functional Histology: A Text and Colour Atlas. Baltimore, MD: Urban \& Schwarzenberg; 1987.

77. Tahmassebi JF, Duggal MS, Malik-Kotru G, Curzon MEJ. Soft drinks and dental health: a review of the current literature. J Dent. 2006;34(1):2-11.

78. Hooper SM, Newcombe RG, Faller R, Eversole S, Addy M, West NX. The protective effects of toothpaste against erosion by orange juice: studies in situ and in vitro. J Dent. 2007;35(6):476-481.

79. Lussi A, Jaeggi T, Schaffner M. Diet and dental erosion. Nutr Oral Health. 2002;18(2):780-781.

80. Johansson K, Sorvari R, Birkhed D, Meurman JH. Dental erosion in deciduous teeth - an in vivo and in vitro study. J Dent. 2001;29(5): 333-340.

81. Low IM, Alhuthali A. In-situ monitoring of dental erosion in tooth enamel when exposed to soft drinks. Mater Sci Eng C. 2008;28(8): 1322-1325.

82. Nunn J, Gordon P, Morris A, Pine C, Walker A. Dental erosion - changing prevalence? A review of British National childrens' surveys. Int $J$ Paediatr Dent. 2003;13(2):98-105.

83. Daly B, Newton TJ, Fares J, et al. Dental tooth surface loss and quality of life in university students. Prim Dent Care. 2011;18(1):31-35.

84. Department of Health [UK]. National Children's Dental Health Survey; 2003. Available from: http://www.dh.gov.uk/en/Publicationsand statistics/Bulletins/Chiefdentalofficersbulletin/Browsable/ DH_4860753. Accessed July 22, 2016.

85. RCS [webpage on the Internet]. State of Children's Oral Health in England; 2015. Available from: https:/www.rcseng.ac.uk/fds/policy/ documents/fds-report-on-the-state-of-childrens-oral-health. Accessed June 23, 2016.

86. O’Sullivan E, Milosevic A. Diagnosis, prevention and management of dental erosion. $R$ Coll Surg. 2007;14:1-17. Available from: https://www. rcseng.ac.uk/fds/publications-clinical-guidelines/clinical_guidelines/ documents/erosion_guideline.pdf. Accessed July 22, 2016.
87. Taji S, Seow WK. A literature review of dental erosion in children. Aust Dent J. 2010;55(4):358-367.

88. Mann C, Ranjitkar S, Lekkas D, et al. Three-dimensional profilometric assessment of early enamel erosion simulating gastric regurgitation. $J$ Dent. 2014;42(11):1411-1421.

89. Okunseri C, Wong MC, Yau DT, McGrath C, Szabo A. The relationship between consumption of beverages and tooth wear among adults in the United States. J Public Health Dent. 2015;75(4):274-281.

90. Zhang J, Du Y, Wei Z, Tai B, Jiang H, Du M. The prevalence and risk indicators of tooth wear in 12- and 15-year-old adolescents in Central China. BMC Oral Health. 2015;15(1):120

91. Kannan A, Adil Ahmed MA, Duraisamy P, Manipal S, Adusumillil P. Dental hard tissue erosion rates and soft drinks - a gender based analysis in Chennai city, India. Saudi J Dental Res. 2014;5(1): 21-27.

92. Kitasako Y, Sasaki Y, Takagaki T, Sadr A, Tagami J. Age-specific prevalence of erosive tooth wear by acidic diet and gastroesophageal reflux in Japan. J Dent. 2015;43(4):418-423.

93. Shellis RP, Finke M, Eisenburger M, Parker DM, Addy M. Relationship between enamel erosion and liquid flow rate. Eur J Oral Sci. 2005; 113(3):232-238

94. Kargul B, Tanboga I, Ergeneli S, Karakoc F, Dagli E. Inhaler medicament effects on saliva and plaque $\mathrm{pH}$ in asthmatic children. J Paedatric Dent. 1198;22(2):137-140.

95. Sivasithamparam K, Young WG, Jirattanasopa V, et al. Dental erosion in asthma: a case-control study from south east Queensland. Aust Dent J. 2002;47(4):298-303.

96. Meurman JH, ten Cate J. Pathogenesis and modifying factors of dental erosion. Eur J Oral Sci. 1996;104(Pt 2):199-206.

97. Fenoglio-Preiser CM, Noffsinger AE, Stemmermann N, Lantz P, Listrom M. The non-neoplastic esophagus. In: Fenoglio-Preiser CM, editor. Gastrointestinal Pathology: An Atlas and Text. Philadelphia: Lippincott-Raven; 1999:31-91.

98. Caufield PW, Griffen AL. Dental caries. An infectious and transmissible disease. Pediatr Clin North Am. 2004;47(5):1001-1019.

99. Douglass J, Douglass A, Slik H. A practical guide to infant oral health. Am Fam Physician. 2004;70(11):2113-2120.

100. Tantbirojn D, Huang A, Ericson MD, Poolthong S. Change in surface hardness of enamel by a cola drink and a CPP-ACP paste. J Dent. 2008;36(1):74-79.

101. Zheng J, Xiao F, Zheng L, Qian LM, Zhou ZR. Erosion behaviors of human tooth enamel at different depth. Tribol Int. 2010;43(7): 1262-1267.

102. Habelitz S. Materials engineering by ameloblasts. J Dent Res. 2015; 94(6):759-767

103. Rios D, Honório HM, Francisconi LF, Magalhães AC, de Andrade Moreira Machado MA, Buzalaf MAR. In situ effect of an erosive challenge on different restorative materials and on enamel adjacent to these materials. J Dent. 2008;36(2):152-157.

104. Regina G, Almeida CD, Sousa CD, et al. Science of the total environment lead contents in the surface enamel of primary and permanent teeth, whole blood, serum, and saliva of 6- to 8-year-old children. Sci Total Environ. 2011;409(10):1799-1805.

105. Hardie J. The microbiology of dental caries. Dent Update. 1982;9(4): 199-208.

106. Nurelhuda NM, Al-Haroni M, Trovik T, Bakken V. Caries experience and quantification of Streptococcus mutans and Streptococcus sobrinus in saliva of Sudanese schoolchildren. Caries Res. 2010;44(4): 402-407.

107. Loesche WJ. Nutrition and dental decay in infants. Am J Clin Nutr. 1985;41(2):423-435.

108. Lussi A, Von Salis-Marincek M, Ganss C, Hellwig E, Cheaib Z, Jaeggi $\mathrm{T}$. Clinical study monitoring the $\mathrm{pH}$ on tooth surfaces in patients with and without erosion. Caries Res. 2012;46(6):507-512.

109. Zheng J, Huang H, Shi MY, Zheng L, Qian LM, Zhou ZR. In vitro study on the wear behaviour of human tooth enamel in citric acid solution. Wear. 2011;271(9-10):2313-2321. 
110. Rytomaa I, Jarvinen V, Kanerva R, Heinonen OP. Bulimia and tooth erosion. Acta Odontol Scand. 1998;56(1):36-40.

111. Hill RG, Gillam DG, Chen X. The ability of a nano hydroxyapatite toothpaste and oral rinse containing fluoride to protect enamel during an acid challenge using $19 \mathrm{~F}$ solid state NMR spectroscopy. Mater Lett. 2015;156:69-71.

112. Lussi A, Megert B, Peter Shellis R, Wang X. Analysis of the erosive effect of different dietary substances and medications. Br J Nutr. 2012; 107(02):252-262.

113. Torres-Gallegos I, Zavala-Alonso V, Patiño-Marín N, MartinezCastañon GA, Anusavice K, Loyola-Rodríguez JP. Enamel roughness and depth profile after phosphoric acid etching of healthy and fluorotic enamel. Aust Dent J. 2012;57(2):151-156.

114. Cairns M, Watson M, Creanor SL, Foye RH. The $\mathrm{pH}$ and titratable acidity of a range of diluting drinks and their potential effect on dental erosion. J Dent. 2002;30(7-8):313-317.

115. Sadler GD, Murphy PA. $p H$ and Titratable Acidity. New York, NY: Springer Science; 2010.

116. Singh S, Jindal R. Evaluating the buffering capacity of various soft drinks, fruit juices and tea. J Conserv Dent. 2010;13(3):129-131.

117. Barbour ME, Shellis RP. An investigation using atomic force microscopy nanoindentation of dental enamel demineralization as a function of undissociated acid concentration and differential buffer capacity. Phys Med Biol. 2007;52(4):899-910.

118. Benjakul P, Chuenarrom C. Association of dental enamel loss with the $\mathrm{pH}$ and titratable acidity of beverages. J Dent Sci. 2011;6(3): 129-133.

119. Perrin DD. Buffers of low ionic strength for spectrophotometric pK determinations. Aust J Chem. 1963;16(4):572-578.

120. Attin T, Becker K, Wiegand A, Taubock TT, Wegehaupt FJ, Tauböck TT. Impact of laminar flow velocity of different acids on enamel calcium loss. Clin Oral Investig. 2013;17(2):595-600.

121. Shellis RP, Dibdin GH. Analysis of the buffering systems in dental plaque. J Dent Res. 1988;67(2):438-446.

122. Finke M, Hughes J, Parker DM, Jandt KD. Mechanical properties of in situ demineralised human enamel measured by AFM nanoindentation. Surf Sci. 2001;491(3):456-467.

123. West NX, Hughes J, Addy M. The effect of $\mathrm{pH}$ on the erosion of dentine and enamel by dietary acids in vitro. J Oral Rehabil. 2001; 28(9):860-864.

124. Abou Neel EA, Bozec L, Perez RA, Kim H-W, Knowles JC. Nanotechnology in dentistry: prevention, diagnosis, and therapy. Intell Surf. 2015;10:6371-6394.

125. Dowd F. Saliva and dental caries. Dent Clin North Am. 1999;43(4): 579-597.

126. Kleinberg I. A new saliva-based anti-caries composition. Dent Today. 1999; 18(2):98-103.

127. Jensen O, Gabre P, Sköld UM, Birkhed D. Is the use of fluoride toothpaste optimal? Knowledge, attitudes and behaviour concerning fluoride toothpaste and toothbrushing in different age groups in Sweden. Community Dent Oral Epidemiol. 2012;40(2): 175-184.

128. Koulourides T. Remineralization methods. Ann N Y Acad Sci. 1968;153:84-101.

129. Bertassoni LE, Marshall G, Swain MV. Mechanical heterogeneity of dentin at different length scales as determined by AFM phase contrast. Micron. 2012;43(12):1364-1371.

130. Jensdottir T, Bardow A, Holbrook P. Properties and modification of soft drinks in relation to their erosive potential in vitro. $J$ Dent. 2005;33(7):569-575.

131. Reynolds E, Cai F, Cochrane N, et al. Fluoride and casein phosphopeptide-amorphous calcium phosphate. J Dent Res. 2008; 87(4):344-348.

132. Reynolds EC, Cai F, Shen P, Walker GD. Retention in plaque and remineralization of enamel lesions by various forms of calcium in a mouthrinse or sugar-free chewing gum. $J$ Dent Res. 2003;82(3): 206-211.
133. Karlinsey RL, Mackey AC, Walker ER, Frederick KE. Surfactantmodified beta-TCP: structure, properties, and in vitro remineralization of subsurface enamel lesions. J Mater Sci Mater Med. 2010;21(7): 2009-2020.

134. Karlinsey R, Pfarrer A. Fluoride plus functionalized b-TCP: a promising combination for robust remineralization. Adv Dent Res. 2012;24(2):48-52.

135. ten Cate J, Cummins D. Fluoride toothpaste containing $1.5 \%$ arginine and insoluble calcium as a new standard of care in caries prevention. J Clin Dent. 2013;24(3):79-87.

136. Zheng $X$, Cheng $X$, Wang L, et al. Combinatorial effects of arginine and fluoride on oral bacteria. J Dent Res. 2015;94(2):344-353.

137. Twetman S. Are we ready for caries prevention through bacteriotherapy? Braz Oral Res. 2012;26(Suppl 1):64-70.

138. Wu CC, Lin CT, Wu CY, Peng WS, Lee MJ, YC T. Inhibitory effect of Lactobacillus salivarius on Streptococcus mutans biofilm formation. Mol Oral Microbiol. 2015;30(1):16-26.

139. Keller M, Nøhr L, Karlsson I, Twetman S. Effect of tablets containing probiotic bacteria (Lactobacillus reuteri) on early caries lesions in adolescents: a pilot study. Benef Microbes. 2014;5(4): 403-407.

140. Lee S, Kim Y. A comparative study of the effect of probiotics on cariogenic biofilm model for preventing dental caries. Arch Microbiol. 2014;196(8):601-609.

141. Haukioja A. Probiotics and oral health. Eur J Dent. 2010;4(3): $348-355$.

142. Schwendicke F, Horb K, Kneist S, Dörfer C, Paris S. Effects of heatinactivated Bifidobacterium BB12 on cariogenicity of Streptococcus mutans in vitro. Arch Oral Biol. 2014;59(12):1384-1390.

143. Saha S, Tomaro-Duchesneau C, Rodes L, Malhotra M, Tabrizian M, Prakash S. Investigation of probiotic bacteria as dental caries and periodontal disease biotherapeutics. Benef Microbes. 2014;5(4): $447-460$.

144. Cildir S, Germec D, Sandalli N, et al. Reduction of salivary mutans streptococci in orthodontic patients during daily consumption of yoghurt containing probiotic bacteria. Eur J Orthod. 2009;31(4): 407-411.

145. Ahmed A, Dachang W, Lei Z, Jianjun L, Juanjuan Q, Yi X. Effect of Lactobacillus species on Streptococcus mutans biofilm formation. Pak J Pharm Sci. 2014;27(5 Spec no):1523-1528.

146. Chinnappa A, Konde H, Konde S, Raj S, Beena JP. Probiotics for future caries control: a short-term clinical study. Indian J Dent Res. 2013;24(5):547-549.

147. Saha S, Tomaro-Duchesneau C, Daoud JT, Tabrizian M, Prakash S. Novel probiotic dissolvable carboxymethyl cellulose films as oral health biotherapeutics: in vitro preparation and characterization. Expert Opin Drug Deliv. 2013;10(11):1471-1482.

148. Nishihara T, Suzuki N, Yoneda M, Hirofuji T. Effects of Lactobacillus salivarius-containing tablets on caries risk factors: a randomized open-label clinical trial. BMC Oral Health. 2014;14:110.

149. Cannon M, Trent B, Vorachek A, Kramer S, Esterly R. Effectiveness of CRT at measuring the salivary level of bacteria in caries prone children with probiotic therapy. J Clin Pediatr Dent. 2013;38(1):55-60.

150. Hillman J, Mo J, McDonell E, Cvitkovitch D, Hillman C. Modification of an effector strain for replacement therapy of dental caries to enable clinical safety trials. J Appl Microbiol. 2007;102(5): 1209-1219.

151. Stock M [webpage on the Internet]. Dental Device Promises PainFree Tooth Repair; 2015. Available from: http://www.reuters.com/ article/us-dental-device-idUSKCN0QU21C20150825. Accessed June 23, 2016.

152. Ferracane JL. Resin composite - state of the art. Dent Mater. 2011;27(1):29-38.

153. Skrtic D, Antonucci JM, McDonough WG, Liu DW. Effect of chemical structure and composition of the resin phase on mechanical strength and vinyl conversion of amorphous calcium phosphate-based composites. J Biomed Mater Res A. 2004;68A(4):763-772. 
154. Skrtic D, Antonucci JM, Eanes ED. Amorphous calcium phosphatebased bioactive polymeric composites for mineralised tissue regeneration. J Res Natl Inst Stand Technol. 2003;108:167-182.

155. Skrtic D, Antonucci JM, Eanes ED, Eichmiller FC, Schumacher GE. Physicochemical evaluation of bioactive polymeric composites based on hybrid amorphous calcium phosphates. J Biomed Mater Res. 2000;53(4):381-391.

156. Skrtic D, Antonucci JM, Eanes ED, Brunworth RT. Silica-and zirconiahybridized amorphous calcium phosphate: effect on transformation to hydroxyapatite. J Biomed Mater Res. 2002;59(4):597-604.

157. Zhao J, Liu Y, Sun WB, Zhang H. Amorphous calcium phosphate and its application in dentistry. Chem Cent J. 2011;5(1):40.

158. Langhorst SE, O’Donnell JNR, Skrtic D. In vitro remineralization of enamel by polymeric amorphous calcium phosphate composite: quantitative microradiographic study. Dent Mater. 2009;25(7):884-891.

159. Weir MD, Chow LC, Xu HHK. Remineralization of demineralized enamel via calcium phosphate nanocomposite. J Dent Res. 2012;91(10):979-984.

160. Melo MAS, Cheng L, Zhang K, Weir MD, Rodrigues LKA, Xu HHK. Novel dental adhesives containing nanoparticles of silver and amorphous calcium phosphate. Dent Mater. 2013;29(2):199-210.

161. O’Donnell JNR, Antonucci JM, Skrtic D. Amorphous calcium phosphate composites with improved mechanical properties. J Bioact Compat Polym. 2006;21(3):169-184

162. Reynolds EC. Calcium phosphate - based remineralization systems: scientific evidence? Aust Dent J. 2008;53(3):268-273.

163. Schumacher GE, Antonucci JM, O’Donnell JNR, Skrtic D. The use of amorphous calcium phosphate composites as bioactive basing materials: their effect on the strength of the composite/adhesive/dentin bond. J Am Dent Assoc. 2007;138(11):1476-1484.

164. Combes C, Rey C. Amorphous calcium phosphates: synthesis, properties and uses in biomaterials. Acta Biomater. 2010;6(9): 3362-3378.

165. Lee SY, Regnault WF, Antonucci JM, Skrtic D. Effect of particle size of an amorphous calcium phosphate filler on the mechanical strength and ion release of polymeric composites. J Biomed Mater Res B Appl Biomater. 2007;80(1):11-17.

166. Skrtic D, Antonucci JM, Liu DW. Ethoxylated bisphenol dimethacrylatebased amorphous calcium phosphate composites. Acta Biomater. 2006;2(1):85-94.

167. Antonucci JM, Skrtic D. Fine-tuning of polymeric resins and their interfaces with amorphous calcium phosphate. A strategy for designing effective remineralizing dental composites. Polymers (Basel). 2010;2(4):378-392.

168. Xu HHK, Moreau JL, Sun L, Chow LC. Nanocomposite containing amorphous calcium phosphate nanoparticles for caries inhibition. Dent Mater. 2011;27(8):762-769.

169. Arcís RW, López-Macipe A, Toledano M, et al. Mechanical properties of visible light-cured resins reinforced with hydroxyapatite for dental restoration. Dent Mater. 2002;18(1):49-57.

170. Domingo C, Arcís RW, Osorio E, et al. Hydrolytic stability of experimental hydroxyapatite-filled dental composite materials. Dent Mater. 2003;19(6):478-486.

171. Santos C, Luklinska ZB, Clarke RL, Davy KWM. Hydroxyapatite as a filler for dental composite materials: mechanical properties and in vitro bioactivity of composites. J Mater Sci Mater Med. 2001;12(7): 565-573.

172. Domingo C, Arcís RW, López-Macipe A, et al. Dental composites reinforced with hydroxyapatite: mechanical behavior and absorption/ elution characteristics. J Biomed Mater Res. 2001;56(2):297-305.

173. Liu F, Wang R, Cheng Y, Jiang X, Zhang Q, Zhu M. Polymer grafted hydroxyapatite whisker as a filler for dental composite resin with enhanced physical and mechanical properties. Mater Sci Eng C Mater Biol Appl. 2013;33(8):4994-5000.

174. Zhang H, Darvell BW. Mechanical properties of hydroxyapatite whisker-reinforced bis-GMA-based resin composites. Dent Mater. 2012;28(8):824-830.
175. Santos C, Clarke RL, Braden M, Guitian F, Davy KWM. Water absorption characteristics of dental composites incorporating hydroxyapatite filler. Biomaterials. 2002;23(8):1897-1904.

176. Chen L, Yu Q, Wang Y, Li H. BisGMA/TEGDMA dental composite containing high aspect-ratio hydroxyapatite nanofibers. Dent Mater. 2011;27(11):1187-1195.

177. Xu HHK, Weir MD, Sun L. Calcium and phosphate ion releasing composite: effect of $\mathrm{pH}$ on release and mechanical properties. Dent Mater. 2009;25(4):535-542.

178. Cheng L, Weir MD, Limkangwalmongkol P, et al. Tetracalcium phosphate composite containing quaternary ammonium dimethacrylate with antibacterial properties. J Biomed Mater Res B Appl Biomater. 2012;100(3):726-734.

179. Xu HHK, Weir MD, Sun L, Takagi S, Chow LC. Effects of calcium phosphate nanoparticles on $\mathrm{Ca}-\mathrm{PO}_{4}$ composite. J Dent Res. 2007;86(4):378-383.

180. Xu HHK, Weir MD, Sun L, et al. Strong nanocomposites with Ca, $\mathrm{PO}_{4}$, and F release for caries inhibition. J Dent Res. 2010;89(1):19-28.

181. Xu HHK, Weir MD, Sun L. Nanocomposites with $\mathrm{Ca}$ and $\mathrm{PO}_{4}$ release: effects of reinforcement, dicalcium phosphate particle size and silanization. Dent Mater. 2007;23(12):1482-1491.

182. Mehdawi I, Pratten J, Spratt DA, Knowles JC, Young AM. High strength re-mineralizing, antibacterial dental composites with reactive calcium phosphates. Dent Mater. 2013;29(4):473-484.

183. Aljabo A, Xia W, Liaqat S, et al. Conversion, shrinkage, water sorption, flexural strength and modulus of reactive calcium phosphate-containing dental composites. Dent Mater. 2015;31(11): 1279-1289.

184. Aljabo A, Abou Neel EA, Knowles JC, Young AM. Development of dental composites with reactive fillers that promote precipitation of antibacterial-hydroxyapatite layers. Mater Sci Eng C Mater Biol Appl. 2016;60:285-292.

185. Youn WG, Khan F. Sites of dental erosion are saliva-dependent. J Oral Rehabil. 2002;29(1):35-43.

186. Boivin G, Meunier P. Changes in bone remodeling rate influence the degree of mineralization of bone. Connect Tissue Res. 2002;43(2-3): 535-537.

187. Sarvraj SK, Virinder SK. Role of RANKL-RANK/osteoprotegerin molecular complex in bone remodeling and its immunopathologic implications. Indian J Endocrinol Metab. 2011;15(3):175-181.

188. Meunier P, Boivin G. Bone mineral density reflects bone mass but also the degree of mineralization of bone: therapeutic implications. Bone. 1997;21(5):373-377.

189. Roschger P, Paschalis E, Fratzl P, Klaushofer K. Bone mineralization density distribution in health and disease. Bone. 2008;42(3): 456-466.

190. Bonfield W, Clark E. Elastic deformation of compact bone. J Mater Sci. 1973;8(11):1590-1594.

191. Boyde A, Travers R, Glorieux F, Jones S. The mineralization density of iliac crest bone from children with osteogenesis imperfecta. Calcif Tissue Int. 1999;64(3):185-190.

192. Weber M, Roschger P, Fratzl-Zelman N, Schöberl T, Rauch F, Glorieux F. Pamidronate does not adversely affect bone intrinsic material properties in children with osteogenesis imperfect. Bone. 2006;39(3):616-622.

193. Roschger S, Misof B, Mann V, et al. Association of COL1A1Sp1 alleles are associated with defective bone mineralization in vivo and in vitro. Calcif Tissue Int. 2004;77(2):113-118.

194. Roschger P, Gupta H, Berzlanovich A, et al. Constant mineralization density distribution in cancellous human bone. Bone. 2003;32(3):316-323.

195. Haas M, Leko-MohrZ, Roschger P, Kletzmayr J, Schwarz C, Mitterbauer C. Zoledronic acid to prevent bone loss in the first six months after renal transplantation. Kidney Int. 2003;63(3):1130-1136.

196. Bodingbauer M, Wekerle T, Pakrah B, et al. Prophylactic bisphosphonate treatment prevents bone fractures after liver transplantation. Am J Transplant. 2007;7(7):1763-1769. 
197. Fratzl-Zelman N, Valenta A, Roschger P, Nader A, Gelb B, Fratzl P. Decreased bone turnover and deterioration of bone structure in two cases of pycnodysostosis. J Clin Endocrinol Metab. 2004;89(4):1538-1547.

198. Imel E, Eckert G, Modi A, et al. Proportion of osteoporotic women remaining at risk for fracture despite adherence to oral bisphosphonates. Bone. 2016;83:267-275.

199. Audrey N, Jean-Yves R. Bone-forming agents in the management of osteoporosis. Best Pract Res Clin Endocrinol Metab. 2008; 22(5):869-883.

200. Modi A, Siris ES, Tang J, Sajjan S, Sen SS. Gastrointestinal events and association with initiation of treatment for osteoporosis. Clinicoecon Outcomes Res. 2015;7:603-613.

201. Favia G, Tempesta A, Limongelli L, Crincoli V, Maiorano E. Medication-related osteonecrosis of the jaw after once-a-year intravenous zoledronic acid infusion for osteoporosis: report of eight cases. Quintessence Int. 2016;47(5):433-440.

202. Deb S, Aiyathurai L, Roether JA, Luklinska ZB. Development of high-viscosity, two-paste bioactive bone cements. Biomaterials. 2005;26(17):3713-3718.

203. Wagoner Johnson AJ, Herschler BA. A review of the mechanical behavior of $\mathrm{CaP}$ and $\mathrm{CaP} /$ polymer composites for applications in bone replacement and repair. Acta Biomater. 2011;7(1):16-30.

204. Kobayashi M, Nakamura T, Okada Y, et al. Bioactive bone cement: comparison of apatite and wollastonite containing glass-ceramic, hydroxyapatite, and beta-tricalcium phosphate fillers on bone-bonding strength. J Biomed Mater Res. 1998;42(2):223-237.

205. Tamura J, Kawanabe K, Kobayashi M, et al. Mechanical and biological properties of two types of bioactive bone cements containing $\mathrm{MgO}$ $\mathrm{CaO}-\mathrm{SiO} 2-\mathrm{P} 2 \mathrm{O} 5-\mathrm{CaF} 2$ glass and glass-ceramic powder. J Biomed Mater Res. 1996;30(1):85-94.

206. Roeder RK, Converse GL, Kane RJ, Yue W. Hydroxyapatite-reinforced polymer biocomposites for synthetic bone substitutes. J Min Metals Mater Soc. 2008;60(3):38-45.

207. Ni GX, Chiu KY, Lu WW, et al. Strontium-containing hydroxyapatite bioactive bone cement in revision hip arthroplasty. Biomaterials. 2006;27(24):4348-4355.

208. Itokawa H, Hiraide T, Moriya M, et al. A 12 month in vivo study on the response of bone to a hydroxyapatite-polymethylmethacrylate cranioplasty composite. Biomaterials. 2007;28(33): 4922-4927.

209. Goto K, Shinzato S, Fujibayashi S, et al. The biocompatibility and osteoconductivity of a cement containing beta-TCP for use in vertebroplasty. J Biomed Mater Res A. 2006;78(3):629-637.

210. Kobayashi M, Nakamura T, Tamura J, Kokubo T, Kikutani T. Bioactive bone cement: comparison of AW-GC filler with hydroxyapatite and beta-TCP fillers on mechanical and biological properties. J Biomed Mater Res. 1997;37(3):301-313.

211. Cama G. Calcium Phosphate Cements for Bone Regeneration. Biomaterials for Bone Regeneration. Sawston: Woodhead Publishing Limited; 2014:3-25.

212. Cama G, Gharibi B, Sait M. A novel method of forming microand macroporous monetite cements. J Mater Chem. 2013;1(7): 958-969.

213. Vereecke G, Jacques L. Calculation of the solubility diagrams in the system $\mathrm{Ca}(\mathrm{OH}) 2-\mathrm{H} 3 \mathrm{PO} 4-\mathrm{KOH}-\mathrm{HNO} 3-\mathrm{CO} 2-\mathrm{H} 2 \mathrm{O}$. J Cryst Growth. 1990;104(4):820-832.

214. Fernández E, Gil F, Ginebra M, Driessen F, Planell J, Best S. Calcium phosphate bone cement for clinical application. Part II: precipitate formation during setting reactions. J Mater Sci Mater Med. 1999;10(3):177-183.
215. Zhang J, Liu W, Schnitzler V, Tancret F, Bouler J. Calcium phosphate cements for bone substitution: chemistry, handling and mechanical properties. Acta Biomater. 2014;10(3):1035-1049.

216. Moroni L, de Wijn JR, van Blitterswijk CA. Integrating novel technologies to fabricate smart scaffolds. J Biomater Sci Polym Ed. 2008;19(5):543-572.

217. Marino A, Filippeschi C, Genchi GG, Mattoli V, Mazzolai B, Ciofani G. The Osteoprint: a bioinspired two-photon polymerized 3-D structure for the enhancement of bone-like cell differentiation. Acta Biomater. 2014;10(10):4304-4313.

218. Rainer W, Erik W, Georg VF, Rudolf S. Direct laser writing-mediated generation of standardized topographies for dental implant surface optimization. J Laser Appl. 2012;24(4):042011.

219. Lan Z, Yong H. Effect of nanostructured titanium on anodization growth of self-organized TiO2 nanotubes. Nanotechnology. 2010;21(5):055602.

220. Brammera K, Ohd S, Cobba C, Bjurstenb L, van der Heydec H, Jin S. Improved bone-forming functionality on diameter-controlled $\mathrm{TiO} 2$ nanotube surface. Acta Biomater. 2009;5(8):3215-3223.

221. Oha S, Brammera K, Julie Lib Y, et al. Stem cell fate dictated solely by altered nanotube dimension. Proc Natl Acad Sci USA. 2009; 106(7):2130-2135.

222. Cavalcanti-Adam E, Volberg T, Micoulet A, Kessler H, Geiger B, Spatz J. Cell spreading and focal adhesion dynamics are regulated by spacing of integrin ligands. Biophys J. 2007;92(8):2964-2974.

223. Ogawa T, Saruwatari L, Takeuchi K, Aita H, Ohno N. Ti nanonodular structuring for bone integration and regeneration. J Dent Res. 2008;87(8):751-756.

224. Goto T. Osseointegration and dental implants. Clin Calcium. 2014; 24(2):265-271.

225. Albrektsson T, Sennerby L, Wennerberg A. State of the art of oral implants. Periodontol 2000. 2008;47:15-26.

226. Mendonça G, Mendonça D, Aragão F, Cooper L. Advancing dental implant surface technology-from micron- to nanotopography. Biomaterials. 2008;29(28):3822-3835.

227. Ciofani G, Ricotti L, Canale C, et al. Effects of barium titanate nanoparticles on proliferation and differentiation of rat mesenchymal stem cells. Colloids Surf B Biointerfaces. 2013;102:312-320.

228. Su W-T, Wu P-S, Ko C-S, Huang T-Y. Osteogenic differentiation and mineralization of human exfoliated deciduous teeth stem cells on modified chitosan scaffold. Mater Sci Eng Mater Biol Appl C. 2014; 41:152-160.

229. Timothy R, Joshua RP, Nageh KA, Xinjian F, Craig AG, Ketul CP. Nanostructured tantala as a template for enhanced osseointegration. Nanotechnology. 2009;20(4):045102.

230. Aminian A, Pardun K, Volkmann E, et al. Enzyme-assisted calcium phosphate biomineralisation on an inert alumina surface. Acta Biomater. 2015;13:335-343.

231. Stadlinger B, Hintze V, Bierbaum S, et al. Biological functionalization of dental implants with collagen and glycosaminoglycans a comparative study. J Biomed Mater Res B Appl Biomater. 2012; 100B(2):331-341.

232. Schliephake H, Scharnweber D, Dard M, Sewing A, Aref A, Roessler S. Functionalization of dental implant surfaces using adhesion molecules. J Biomed Mater Res B Appl Biomater. 2005;73B(1):88-96.

233. Puleo D, Kissling R, Sheu M. A technique to immobilize bioactive proteins, including bone morphogenic protein-4 (BMP-4), on titanium alloy. Biomaterials. 2002;23(9):2079-2087.

234. Kapustin A, Davies J, Reynolds J, et al. Calcium regulates key components of vascular smooth muscle cell-derived matrix vesicles to enhance mineralization. Circ Res. 2015;109(1):e1-e12. 
International Journal of Nanomedicine

Dovepress

\section{Publish your work in this journal}

The International Journal of Nanomedicine is an international, peerreviewed journal focusing on the application of nanotechnology in diagnostics, therapeutics, and drug delivery systems throughout the biomedical field. This journal is indexed on PubMed Central, MedLine, CAS, SciSearch ${ }^{\circledR}$, Current Contents ${ }^{\circledR} /$ Clinical Medicine,
Journal Citation Reports/Science Edition, EMBase, Scopus and the Elsevier Bibliographic databases. The manuscript management system is completely online and includes a very quick and fair peer-review system, which is all easy to use. Visit http://www.dovepress.com/ testimonials.php to read real quotes from published authors.

Submit your manuscript here: http://www.dovepress.com/international-journal-of-nanomedicine-journal 